\title{
The Antiangiogenic Activity of Naturally-occurring and synthetic Homoisoflavonoids from the Hyacinthaceae (sensu APGII)
}

\author{
Sianne Schwikkard ${ }^{\dagger, \ddagger}$, Hannah Whitmore ${ }^{\ddagger}$, Kamakshi Sishtla ${ }^{\S}$, Rania S. Sulaiman $\S^{\S} \S^{\prime}, \perp$, \\ Trupti Shetty $\S^{\S} \S^{\prime}$, Halesha D. Basavarajappa $\S^{\S} \S^{\prime \prime}$, Catherine Waller ${ }^{\ddagger}$, Alaa Alqahtani ${ }^{\ddagger}$, Lennart \\ Frankemoelle $^{\dagger}$, Andy Chapman ${ }^{\dagger}$, Neil Crouch $\|, \#$, Wolfgang Wetschnig ${ }^{\nabla}$, Walter Knirsch ${ }^{\nabla}$, \\ Jacky Andriantiana ${ }^{\bigcirc}$, Eduard Mas-Claret ${ }^{\ddagger}$, Moses K Langat ${ }^{\ddagger}, \#$, Dulcie Mulholland ${ }^{\ddagger},,^{*}$, \\ Timothy W. Corson $\S, \S^{\prime}, \S^{\prime \prime}, *$ \\ †School of Life Sciences, Pharmacy and Chemistry, Kingston University, Kingston-upon-Thames, \\ KT1 2EE, UK. \\ ¥Natural Products Research Group, Department of Chemistry, Faculty of Engineering and \\ Physical Sciences, University of Surrey, Guildford, GU2 7XH, United Kingdom. \\ §Eugene and Marilyn Glick Eye Institute, Department of Ophthalmology, Indiana University School \\ of Medicine, 1160 W. Michigan St., Indianapolis, IN 46202, U.S.A. \\ §'Department of Pharmacology and Toxicology, Indiana University School of Medicine, $1160 \mathrm{~W}$. \\ Michigan St., Indianapolis, IN 46202, U.S.A. \\ §"Department of Biochemistry and Molecular Biology, Indiana University School of Medicine, 1160 \\ W. Michigan St., Indianapolis, IN 46202, U.S.A. \\ ${ }^{\perp}$ Department of Biochemistry, Faculty of Pharmacy, Cairo University, Cairo, Egypt. \\ \| Biodiversity Economy, South African National Biodiversity Institute, P.O. Box 52099, 4007 Berea \\ Road, Durban, South Africa. \\ ${ }^{\nabla}$ Institute of Biology, NAWI Graz, University of Graz, 8010 Graz, Austria. \\ OParc Botanique et Zoologique de Tsimbazaza, Rue Fernand Kassanga, Antananarivo 101, \\ Madagascar \\ \#School of Chemistry and Physics, University of KwaZulu-Natal, Durban, 4041, South Africa.
}

\begin{abstract}
Excessive blood vessel formation in the eye is implicated in wet age-related macular degeneration, proliferative diabetic retinopathy, neovascular glaucoma and retinopathy of prematurity, which are major causes of blindness. Small molecule antiangiogenic drugs are strongly needed to supplement existing biologics. Homoisoflavonoids have been previously shown to have potent anti-proliferative activities in endothelial cells over other cell types. Moreover, they demonstrated a strong antiangiogenic potential in vitro and in vivo in animal models of ocular neovascularization. Here, we tested the antiangiogenic activity of a group of naturally occurring
\end{abstract}

\footnotetext{
*Corresponding Authors: Tel: +44 (0)1483 301080. d.mulholland@surrey.ac.uk; Tel: +1 (317) 274-3305. tcorson@iu.edu. 
homoisoflavonoids isolated from the family Hyacinthaceae and related synthetic compounds, chosen for synthesis based on structure activity relationship observations. Several compounds showed interesting anti-proliferative and antiangiogenic activities in vitro on retinal microvascular endothelial cells, a disease-relevant cell type, with the synthetic chromane, 46, showing the best activity $\left(\mathrm{GI}_{50}\right.$ of $\left.2.3 \times 10^{-4} \mu \mathrm{M}\right)$.

\section{Graphical Abstract}<smiles>COc1ccc(C[C@H]2COc3cc(OC)c(OC)c(OC)c3C2)cc1O</smiles>

\section{$\mathrm{GI}_{50} 2.3 \times 10^{-4} \mu \mathrm{M}$}

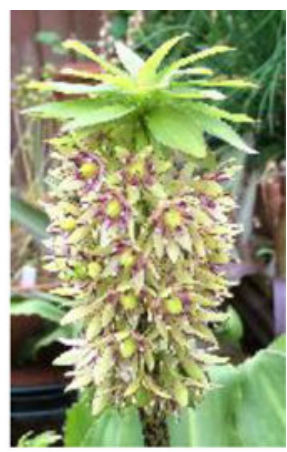

(human retinal microvascular endothelial cells)

Abnormal formation of new blood vessels in the eye is associated with blindness in many ocular diseases such as retinopathy of prematurity (ROP) affecting children, proliferative diabetic retinopathy (PDR), the wet form of age-related macular degeneration (AMD) and neovascular glaucoma affecting adults, and elderly people, respectively. ${ }^{1}$ The newly formed vasculature is fragile and leaky causing hemorrhage and accumulation of fluids in the retina. If left untreated, the resulting edema and fibrotic scarring can lead to irreversible vision loss. 2 The current pharmacotherapeutic mainstays for these diseases are biologics targeting the vascular endothelial growth factor (VEGF) such as bevacizumab, ranibizumab, and aflibercept. ${ }^{3}$ Despite being successful in suppressing disease progression, these large molecule therapies are associated with some undesirable ocular and systemic side effects as well as the time consuming regular visits to hospitals required for the intravitreal injections. 4,5 Moreover, resistance is a problem: about $30 \%$ of wet AMD patients are resistant to these biologics. ${ }^{6}$ Currently, there is no FDA approved small molecule for the treatment of ocular neovascularization. Therefore, there is an unmet need to develop novel and specific antiangiogenic small molecule therapies to complement and combine with existing drugs for ROP, PDR, and wet AMD.

Natural products continue to provide appealing lead compounds for treatment of diseases. ${ }^{7}$ Naturally occurring homoisoflavonoids are reported to have diverse biological activities including antioxidant, anti-inflammatory and antiangiogenic activities. ${ }^{8}$ The Hyacinthaceae is one of the families rich in homoisoflavonoids distributed in different parts of the plants. The Hyacinthaceae (sensu APGII) consists of approximately 900 species, in about 70 genera. The family can be divided into four subfamilies, the widespread Hyacinthoideae, Urgineoideae and Ornithogaloideae and the small sub-family Oziroëoideae which is restricted to South America. For the most part, the compounds found are sub-family 
restricted. Homoisoflavonoids and spirocyclic nortriterpenoids characterise the Hyacinthoideae, bufadienolides the Urgineoideae and cardenolides and steroidal glycosides the Ornithogaloideae. To date, no phytochemical investigations have been reported of the Oziroëoideae. $^{9}$

Members of the Hyacinthoideae subfamily have a long tradition of being used by traditional healers to treat a wide range of complaints. Phytochemical investigations of the genus Eucomis L'Hér., ${ }^{10}$ Ledebouria revoluta (L.F.) Jessop, ${ }^{11}$ Ledebouria ovatifolia (Baker) Jessop, ${ }^{12}$ Merwilla plumbea (Lindl.) Speta ${ }^{13}$ all widely used in African traditional medicine, have been reported.

Previously, a homoisoflavanone, cremastranone, isolated from the orchid Cremastra appendiculata (D.Don) Makino, was shown to have antiangiogenic activity in the ocular context, but unfortunately, the configuration at C-3 was not reported. ${ }^{14-16}$ This compound was also previously isolated from the Hyacinthoideae genera Muscari Mill., ${ }^{17}$ and Merwilla Speta. ${ }^{13}$ More recently, a synthetic racemate of this compound showed strong antiangiogenic activity against human retinal microvascular endothelial cells (HRECs), with lesser effects on non-endothelial cell types. ${ }^{18}$ A synthetic regioisomer of cremastranone (SH-11052) also had antiangiogenic activities in vitro. ${ }^{19}$ Subsequently, our SAR campaign identified a promising synthetic analogue of cremastranone, named SH-11037, with more potent and selective antiproliferative effects on HRECs compared to endothelial cells of macrovascular origin. ${ }^{20}$ Moreover, $\mathrm{SH}-11037$ demonstrated strong antiangiogenic potential in vivo in animal models of $\mathrm{ROP}^{20}$ and choroidal neovascularization. ${ }^{21}$ We have also isolated known and novel homoisoflavonoids from Massonia Houtt. species, some of which showed selective antiproliferative effects on HRECs. ${ }^{22}$ Given the selective and potent antiangiogenic activity of cremastranone and derivatives, the search for further antiangiogenic homoisoflavonoids is warranted. In parallel with our medicinal chemistry approach, ${ }^{20}$ we have here further explored natural-source and related synthetic homoisoflavonoids as antiangiogenic agents.

Homoisoflavonoids and related compounds isolated from seven species of Hyacinthaceae have been investigated in this study for antiangiogenic activity. The isolation and structure determination of compounds from Ledebouria socialis (Baker) Jessop $(\mathbf{1}, \mathbf{2})$, Ledebouria ovatifolia (Baker) Jessop (3-14), Rhodocodon campanulatus Knirsch (25, 26), Mart-Azorín and Wetschnig, Rhodocodon aff. intermedius Knirsch, Mart-Azorín and Wetschnig (27-29), have been reported by us previously and compounds from these sources were screened as part of this work. ${ }^{23,24}$ In addition, Chionodoxa luciliae Boiss, Eucomis autumnalis (Mill.) Chitt. and Eucomis bicolor Baker were re-investigated to provide material for screening and a previously unreported homoisoflavonoid, $\mathbf{3 5}$, along with previously reported ones were isolated, some for the first time from these sources. These species were chosen for reextraction due to large amounts of bulb material being available from a commercial supplier enabling us to isolate large amounts of compounds for screening purposes.

In addition, based on our cell-based structure-activity observations, a number of known (44, $47,48)$ and previously undescribed homoisoflavonoids $(42,43,45,46,49$ and 50$)$ were synthesized and investigated for antiangiogenic activity, including the enantioselective 
synthesis of compound 45 with the $3 R$ configuration. Compound 46 , a previously undescribed compound with a chromane skeleton, showed significantly greater activity than the related chromanones (45 and $\mathbf{4 7})$.

\section{RESULTS AND DISCUSSION}

The EtOH extract of the bulbs of Chionodoxa luciliae Boiss yielded compound 16, parahydroxybenzaldehyde, and homoisoflavonoids 15, 17 and 21-24. Compound 17 was acetylated and yielded the 7-acetate (19) and 3,7-diacetate (20). Compound 16 is likely to be a degradation product of compound $\mathbf{2 1}$. All compounds have been reported previously from several sources ${ }^{9,25}$ but this is the first report of the isolation of compounds 17, 22 and $\mathbf{2 3}$ from a Chionodoxa species. Structures were determined using NMR techniques and were confirmed by comparison against literature data; the configurations at C-3 were confirmed using circular dichroism spectroscopy and optical rotation measurements.

The $\mathrm{MeOH}$ and butanol extracts of the bulbs of Eucomis autumnalis yielded compounds $\mathbf{2 2}$ and 30-39 and the EtOH extract of the bulbs of E. bicolor yielded compounds 40 and 41. Compounds $\mathbf{3 1}$ and $\mathbf{3 2}$ have been isolated previously from both E. autumnalis and E. bicolor, 26 compound $\mathbf{3 6}$ from E. autumnalis, ${ }^{27,28,29}$ compounds 30, $\mathbf{4 0}$ and $\mathbf{4 1}$ from E. bicolor, $27,30,31$ compound $\mathbf{3 3}$ from E. montana, ${ }^{32}$ compound $\mathbf{3 8}$ from Muscari armeniacum, ${ }^{17}$ compound $\mathbf{3 9}$ from Scilla persica ${ }^{33}$ and compound $\mathbf{3 7}$ from Ledebouria ovatifolia. ${ }^{23}$

Compound 35, 3R-(4'-hydroxybenzyl)-6,8-dihydroxy-5,7-dimethoxy-4-chromanone, is a homoisoflavonoid that has not been reported previously with a fully substituted ring A. HRMS showed a protonated molecular ion at $\mathrm{m} / \mathrm{z} 347.11254$ corresponding to a molecular formula of $\mathrm{C}_{18} \mathrm{H}_{18} \mathrm{O}_{7}$. Characteristic peaks at $\delta_{\mathrm{H}} 4.37(\mathrm{H}-2 \mathrm{a}, \mathrm{dd}, 11.4,4.1 \mathrm{~Hz}), \delta_{\mathrm{H}} 4.20$ $(\mathrm{H}-2 \beta, \mathrm{dd}, 11.4,7.2 \mathrm{~Hz}), 2.79(\mathrm{H}-3, \mathrm{~m}), \delta_{\mathrm{H}} 3.17(\mathrm{H}-9 \mathrm{~A}, \mathrm{dd}, 14.0,4.4 \mathrm{~Hz})$ and $\delta_{\mathrm{H}} 2.70$ $(\mathrm{H}-9 \mathrm{~B}, \mathrm{dd}, 14.0,10.6 \mathrm{~Hz})$ were indicative of a 3-benzyl-4-chromanone structure and resonances at $\delta_{\mathrm{H}} 6.79\left(2 \mathrm{H}, 3^{\prime}, 5^{\prime}, 8.1 \mathrm{~Hz}\right)$ and $\delta_{\mathrm{H}} 7.11\left(2 \mathrm{H}, 2^{\prime}\right.$ and $\left.6^{\prime}, 8.1 \mathrm{~Hz}\right)$ showed that the $\mathrm{B}$ ring was para-disubstituted. The two $\mathrm{H}-2$ and two $\mathrm{H}-9$ resonances showed correlations with the C-4 keto group carbon resonance at $\delta_{\mathrm{C}}$ 192.0. Two methoxy group proton resonances and three exchangeable hydroxy group proton resonances $\left(\delta_{\mathrm{H}} 5.59,6-\mathrm{OH} ; \delta_{\mathrm{H}}\right.$ $5.39,8-\mathrm{OH}$ and $\delta_{\mathrm{H}} 4.74,4^{\prime}-\mathrm{OH}$ ) could be assigned from correlations seen in the HMBC spectrum (Figure 1). A specific rotation of -55.6 and negative Cotton effect at $290 \mathrm{~nm}$ indicated a $3 R$-configuration. ${ }^{11}$ Homoisoflavonoids with a fully substituted ring A are rare with only two similar compounds being reported previously: (4'-hydroxybenzyl)-5,6dihydroxy-7,8-dimethoxy-4-chromanone, from Bellevalia eigii ${ }^{34}$ and (4'-hydroxy)-5,8dihydroxy-6,7-dimethoxy-4-chromanone, from Muscari comosum. 35

Previous work on synthetic analogues of cremastranone demonstrated that much potential remained for the improvement of activity. Previously, 3-benzyl analogues had been synthesised as racemic mixtures and we wished to investigate the possibility of synthesising a single enantiomer via selective hydrogenation of the 3,9-double bond of a 3-benzylidene analogue. In addition, the effect of producing the chromane derivative of 5,6,7-trimethoxy-3(3'-hydroxy-4'-methoxybenzylidene)-4-chromanone was of interest. Homoisoflavonoids 42 to 49 were synthesised following known methods ${ }^{36}$ (Schemes 1 and 2). An iridium catalyst, 
the (S)-4-tert-butyl-2-[2-(diphenylphosphino)phenyl]-2-oxazoline complex, also known as iridium-phosphino-oxazoline or phox, used to hydrogenate compound $\mathbf{4 4}$ to form $\mathbf{4 5}$, was synthesised using known methodology ${ }^{37}$ and is shown in Scheme 2. Chalcone $\mathbf{5 0}$ was synthesised via a Claisen-Schmidt condensation, using known methods. ${ }^{38}$

Syntheses of compounds $\mathbf{4 4 , 4 7}$ and $\mathbf{4 8}$ have been reported ${ }^{20,39}$ while the synthesis of compounds 42, 43, 45, 46, 49 and 50 has not been reported before. Compounds 42 and 43 were both synthesised in low yield ( 3 and $3.5 \%$ respectively). The first two steps proceeded well, with the low yield being a result of poor reaction completion in step three and extensive chromatography to produce the pure product. The structures were confirmed by high resolution mass spectrometry and NMR analysis.

Compound $\mathbf{4 4}$ was used as a starting point for our investigation into the asymmetric hydrogenation of the 3,9-double bond in the benzylidene-type homoisoflavonoids using the iridium catalyst (Scheme 2) for the hydrogenation. The reaction proceeded quantitatively to give compound $\mathbf{4 5}$.

A systematic conformational search of $3 R$ - and $3 S$-isomers of 5,6,7-trimethoxy-( $3^{\prime}$ hydroxy-4'-methoxybenzyl)-4-chromanone was performed via molecular mechanics force field calculation (MMFF) built in the software Spartan'16. Conformers under $3.0 \mathrm{~kJ} / \mathrm{mol}$ relative energy cut-off were selected and optimised using Density Functional Theory (DFT) calculations at B3LYP/6-31 G + (d,p) level built into Gaussian09. Once optimised, their ECD spectra were simulated using Time Dependant Density Functional Theory (TDDFT) at the B3LYP/6-31 + G (d,p) level. A polarisable continuum model (IEFPCM) was applied during the TDDFT calculation to simulate the presence of acetonitrile, which was the solvent used in the experimental ECD. The ECD spectra obtained for each conformer were Boltzmann weighted and compared to the experimental ECD spectrum of 45. ${ }^{40}$ The $6-31+$ $\mathrm{G}(\mathrm{d}, \mathrm{p})$ basis set was applied as it provides a fine balance between accuracy and computational time needed. In addition, it has been applied in the past by our group with satisfactory results. ${ }^{41}$

The measured ECD spectrum of $\mathbf{4 5}$ showed a positive Cotton effect at $\lambda(\Delta \varepsilon) 326(+1.3)$ and a negative Cotton effect at $\lambda(\Delta \varepsilon) 284(-1.9)$, which is in accordance with the theoretical calculated spectrum for the $3 R$-enantiomer, indicating the $3 R$ configuration for compound 45 (Supporting Information). ${ }^{42}$ For comparative purposes compound $\mathbf{4 4}$ was hydrogenated using $\mathrm{Pd} / \mathrm{C}$ to give the racemic mixture, 46. This reaction resulted in the reduction of both the 3,9-double bond as well as the carbonyl group at C-4 as shown by the loss of the fully-substituted carbon resonance at $\delta_{\mathrm{C}} 179.8$ (C-4) and the new methylene resonance at $\delta_{\mathrm{C}} 37.5(\mathrm{C}-4)$. Coupling could clearly be seen in the COSY spectrum between the resonance at $\delta_{\mathrm{H}} 2.14(1 \mathrm{H}, \mathrm{m}, \mathrm{H}-3)$ and the resonance at $\delta_{\mathrm{H}} 2.53(2 \mathrm{H}, \mathrm{dd}, J=4.1$ and 7.4 $\mathrm{Hz}, \mathrm{H}-4)$. Compound $\mathbf{4 4}$ was then successfully hydrogenated using Wilkinson's catalyst (tris(triphenylphosphine)rhodium(I) chloride) to give compound $\mathbf{4 7}$, the previously synthesised racemate. ${ }^{20}$ Compound $\mathbf{4 8}$ was synthesised to determine whether the presence of a 5-OH group was significant for activity. Many natural homoisoflavonoids have a hydroxyl group at C-5. The selective demethylation was confirmed by the appearance of a sharp 
singlet at $\delta_{\mathrm{H}} 12.45$, due to the proton of a $\mathrm{H}$-bonded hydroxyl group at C-5. In addition, three methoxy groups were noted instead of four.

Compound 49 was synthesised from 3,4,5-trimethoxyphenol and 4-chloro-3hydroxybenzaldehyde and the expected product was formed. A HRESIMS value of $\mathrm{m} / \mathrm{z}$ $377.0786[\mathrm{M}+\mathrm{H}]^{+}$indicated a molecular formula of $\mathrm{C}_{19} \mathrm{H}_{17} \mathrm{O}_{6} \mathrm{Cl}$. The structure of the product was confirmed by key ${ }^{1} \mathrm{H}$ NMR resonances at $\delta_{\mathrm{H}} 4.99(2 \mathrm{H}, \mathrm{d}, J=1.8 \mathrm{~Hz}, \mathrm{H}-2), 7.75$ $(1 \mathrm{H}, \mathrm{bs}, \mathrm{H}-9), 6.16(1 \mathrm{H}, \mathrm{s}, \mathrm{H}-8)$ and three methoxy group three-proton resonances at $\delta_{\mathrm{H}} 3.75$ $(3 \mathrm{H}, \mathrm{s}), 3.82(3 \mathrm{H}, \mathrm{s})$ and $3.91(3 \mathrm{H}, \mathrm{s})$. The B-ring resonances at $\delta_{\mathrm{H}} 7.15(1 \mathrm{H}, \mathrm{dd}, J=2.4$ and $\left.8.6 \mathrm{~Hz}, \mathrm{H}-2^{\prime}\right), 6.91\left(1 \mathrm{H}, \mathrm{d}, J=2.4, \mathrm{H}-6^{\prime}\right)$ and $6.83\left(1 \mathrm{H}, \mathrm{d}, J=8.6, \mathrm{H}-3^{\prime}\right)$ supported the $4^{\prime}$, $5^{\prime}$-substitution pattern.

Compound 50, a chalcone, was synthesised from 3,4-dimethoxybenzaldehyde and 4'ethoxy-2'-hydroxy-3'-methylacetophenone via a Claisen-Schmidt condensation. The HRESIMS gave a $[\mathrm{M}+\mathrm{H}]^{+}$ion at $\mathrm{m} / \mathrm{z} 343.1545$, giving a molecular formula of $\mathrm{C}_{20} \mathrm{H}_{22} \mathrm{O}_{5}$ for the compound. The chalcone structure was confirmed by a pair of doublets in the ${ }^{1} \mathrm{H}$ NMR spectrum at $\delta_{\mathrm{H}} 7.47(1 \mathrm{H}, \mathrm{d}, J=15.2 \mathrm{~Hz}, \mathrm{H}-2)$ and $7.84(1 \mathrm{H}, \mathrm{d}, J=15.2 \mathrm{~Hz}, \mathrm{H}-3)$ indicative of $E$ geometry.

\section{Antiproliferative activities of homoisoflavonoids}

To find novel antiangiogenic homoisoflavonoids, compounds were tested for their antiproliferative activities on HRECs. To assess effects on other normal cell types, we tested compounds against primary macrovascular human umbilical vein endothelial cells (HUVECs; a non-target endothelial cell type) or the retinal pigment epithelial cell line, ARPE-19, a non-target ocular cell type. Ideal antiangiogenic candidates should have lesser effects on these non-target cell types than on HRECs. To further assess potential cytotoxic effects against ocular cell types, we also employed two ocular cancer cell lines, uveal melanoma 92-1 and retinoblastoma Y79. Again, ideal candidates for further investigation as antiangiogenic homoisoflavonoids should show lower activity against these other ocular cell lines derived from uveal melanocytes and photoreceptor precursors, respectively.

While many of the compounds lacked activity against the cell types, some compounds were reasonably potent and selective for the endothelial cell types (Tables 1 and 2; Figures 2-4). The results would suggest some structural features are significant in determining the activity of the homoisoflavonoid. Optimal activity was observed when the A-ring was either 5,6,7trisubstituted or 5,7-disubstituted. If only two substituents were present, at least one of them would need to be an acetyl rather than a hydroxy group. $3^{\prime}, 4^{\prime}$-Disubstitution in ring B produced the highest activity, in particular when combined with the presence of a 3/9 double bond. Homoisoflavonoids with the bulkier $3^{\prime}$-acetyl group were more active than ones with the $3^{\prime}$-hydroxyl group. The presence of a cyclobutane ring rendered the homoisoflavonoid inactive, regardless of the substituents on rings $A$ and $B$. The importance of a 5,6,7trisubstituted A-ring was confirmed by the synthetic samples, with the trisubstituted compounds $(\mathbf{4 4}, \mathbf{4 5}, \mathbf{4 6}, \mathbf{4 7}, 48$ and 49$)$ showing better activity than the disubstituted compounds ( 42 and $\mathbf{4 3}$ ). Interestingly, the $3 R$-enantiomer $(\mathbf{4 5})$ showed greater activity than the precursor with a double bond in the 3,9-position (44) as well as greater activity than the racemic mixture (47). This serves to emphasise the importance of being able to synthesise 
these homoisoflavonoids enantioselectively. The complete reduction of both the 3,9-double bond and the carbonyl group at C-4 produced a highly active compound (46) (Table 2, $\mathrm{GI}_{50}$ (HREC) of $2.3 \times 10^{-4} \mu \mathrm{M}, \mathrm{GI}_{50}$ (ARPE-19) of $3.4 \times 10^{-4} \mu \mathrm{M}$, and $\mathrm{GI}_{50}(92-1)$ of $52 \mu \mathrm{M}$ ). This significant increase in activity with the loss of the carbonyl group at C-4 has not been reported before, although this compound was synthesized simultaneously by the Seo lab (personal communication). Compound 49, with a 4'-chloro-3'-hydroxyphenylbenzylidene group at C-3 produced good activity with selectivity for HRECs (Table 2, $\mathrm{GI}_{50}$ (HREC) of $0.11 \mu \mathrm{M}, \mathrm{GI}_{50}(92-1)$ of $3.6 \mu \mathrm{M}$ ), compared to that of compound 44 (Table 2, GI ${ }_{50}$ (HREC) of $2.2 \mu \mathrm{M}, \mathrm{GI}_{50}(92-1)$ of $\left.8.2 \mu \mathrm{M}\right)$. By way of comparison, cremastranone as reported was substantially less potent, but still selective (GI $\mathrm{GI}_{50}$ (HREC) of $0.22 \mu \mathrm{M}, \mathrm{GI}_{50}$ (HUVEC) of $0.38 \mu \mathrm{M}, \mathrm{GI}_{50}(92-1)$ of $48 \mu \mathrm{M}, \mathrm{GI}_{50}(\mathrm{Y} 79)$ of $\left.9.8 \mu \mathrm{M}\right){ }^{20}$

\section{In vitro antiangiogenic efficacy of the potent homoisoflavonoids}

After identifying some of the most potent anti-proliferative compounds with some selectivity for HRECs - compounds $13,27, \mathbf{2 8}, \mathbf{4 5}, \mathbf{4 6}, \mathbf{4 8}$, and 50- we further investigated their potential in inhibiting the ability of HRECs to form tubes. Matrigel based tube formation is the gold-standard in vitro assay that recapitulates most of the physiological angiogenesis events such as cell proliferation, migration, and cell-cell adhesion, as endothelial cells form three dimensional tube-like structures. ${ }^{43}$ Interestingly, all three of the natural-source compounds $(\mathbf{1 3}, \mathbf{2 7}$, and $\mathbf{2 8})$, inhibited the ability of HRECs to form tubes in a concentration-dependent manner (Figure 3). Three potent synthetic compounds, 48, 45, and 50, were also effective (Figure 4), while the most potent antiproliferative compound, $\mathbf{4 6}$, maintained this low-dose efficacy in the tube formation assay (Figure 5).

\section{CONCLUSIONS}

A group of naturally occurring homoisoflavonoids isolated from the Hyacinthaceae as well as compounds synthesized have been tested for their antiangiogenic activities. The most potent compounds, 13, 28, 29, 42, 43, 45, 46, 48 and the chalcone 50, demonstrated selective antiproliferative activities on endothelial cells compared to non-endothelial cell types, with concentration-dependent antiangiogenic effects in vitro on HRECs, a disease-relevant cell type. Recently, intracellular target proteins for some other bioactive homoisoflavonoids have been identified: ferrochelatase as a target of cremastranone, ${ }^{44}$ soluble epoxide hydrolase as a target of SH-11037 (a synthetic Boc-Phe-derivatized homoisoflavonoid), ${ }^{45}$ and inosine monophosphate dehydrogenase 2 as a target of sappanone A. ${ }^{46}$ The relative effects of the natural products described here on each of these enzymes will be a valuable topic for future exploration. Our results will open the doors to the development of further synthetic analogues with higher potency and better antiangiogenic activities to treat blinding eye diseases caused by pathological neovascularization.

\section{EXPERIMENTAL SECTION}

\section{General Experimental Procedures.}

NMR spectra were recorded on a 500MHz Bruker AVANCE NMR instrument in either $\mathrm{CDCl}_{3}$ or $\mathrm{CD}_{3} \mathrm{OD}$ at room temperature. All chemical shifts $(\delta)$ are in ppm and referenced to 
the relevant solvent references, $7.26 \mathrm{ppm}\left(\mathrm{CDCl}_{3}\right)$ and $4.87 \mathrm{ppm}\left(\mathrm{CD}_{3} \mathrm{OD}\right)$ for ${ }^{1} \mathrm{H}$ NMR spectra and $77.23 \mathrm{ppm}\left(\mathrm{CDCl}_{3}\right)$ and $49.15 \mathrm{ppm}\left(\mathrm{CD}_{3} \mathrm{OD}\right)$ for ${ }^{13} \mathrm{C}$ NMR spectra. ESI mass spectra were either recorded on a Bruker MicroToF mass spectrometer using an Agilent 1100 HPLC to introduce samples (University of Oxford), a Micromass Quattro Ultima mass spectrometer using a Waters Alliance HPLC to introduce samples (University of Surrey) or a Waters Xevo G2-S (National Mass Spectrometry Facility, Swansea). Optical rotations were recorded in $\mathrm{CDCl}_{3}$ on a JASCO P-1020 polarimeter (University of Surrey), IR spectra were recorded on a Perkin-Elmer 2000 spectrometer (University of Surrey), and UV spectra were recorded using a Biochrom libraS60 in $\mathrm{MeOH}$ or acetonitrile in a $1 \mathrm{~cm}$ cell (University of Surrey). CD spectra were recorded using a Chirascan spectropolarimeter at room temperature in a $1 \mathrm{~cm}$ cell in $\mathrm{MeOH}$ (University of Surrey). Reagents were purchased from Sigma-Aldrich Company Ltd, Gillingham, UK, SP8 4XT and used without further purification.

\section{Plant Material.}

The sourcing of plant material, extraction methodology and isolation of compounds from the bulbs of $L$. ovatifolia (Bak.) Jessop, $L$ socialis (Bak.) Jessop, Rhodocodon campanulatus Knirsch, Mart Azorin \& Wetschnig and Rhodocodon aff. intermedius have been described before. ${ }^{24,25}$ Bulbs of Chinodoxa. luciliae Boiss. (Gigantea Hort), Eucomis autumnalis (Mill.) Chitt. and E. bicolor Baker were purchased from the Dix Export Company (Netherlands) in 2012 and grown to produce a flowering specimen to confirm identification. Voucher specimens (DAM 2012 CL, EA and EB) are retained at the University of Surrey.

\section{Extraction and Isolation.}

Dried bulbs of Chinodoxa luciliae ( $3.0 \mathrm{~kg}$ ) were extracted in EtOH at room temperature for 24 hours on a shaker. The resulting extract ( $119 \mathrm{~g}$ ) was separated using gravity column chromatography over silica gel (Merck 9385) and solvent mixtures of 80:20 $\mathrm{CH}_{2} \mathrm{Cl}_{2}$ :EtOAc (75 $\mathrm{cm}^{-3}, 75$ fractions) and 70:30 $\mathrm{CH}_{2} \mathrm{Cl}_{2}$ :EtOAc $\left(75 \mathrm{~cm}^{-3}, 10\right.$ fractions). Further purification was necessary in some cases using PTLC (Macherey-Nagel $0.25 \mathrm{~mm}$, silica gel 60 with fluorescent indicator $\mathrm{UV}_{254}$ ), further column chromatography or acetylation of complex mixtures to obtain pure compounds. Fraction 68 yielded $15(11 \mathrm{mg})$, fraction 70 yielded, after further purification, $\mathbf{1 6}(2 \mathrm{mg})$ and $\mathbf{1 7}(10 \mathrm{mg})$, fraction 72 yielded $\mathbf{1 8}(17 \mathrm{mg})$ and after acetylation of a mixture containing 17, the monoacetate, $\mathbf{1 9}(15 \mathrm{mg})$ and diacetate (12 mg), 20. Fraction 74 yielded, after further purification, $21(20 \mathrm{mg})$ and $22(20 \mathrm{mg})$, Fraction 77 yielded $23(50 \mathrm{mg})$ and fraction 80 yielded $\mathbf{2 4}(15 \mathrm{mg})$. Compounds were identified using 2D NMR and CD methods and by comparison against literature data as referenced earlier.

Chopped bulbs of E. autumnalis ( $4 \mathrm{~kg}$ ) were extracted with $\mathrm{MeOH}(3 \mathrm{~L})$ for 48 hours yielding an extract which was partitioned with $\mathrm{CH}_{2} \mathrm{Cl}_{2}(300 \mathrm{ml})$ to yield extract $1(5.1 \mathrm{~g})$ after solvent evaporation. Bulb material was further extracted in 1-butanol $(2.5 \mathrm{~L})$ for 24 hours, yielding extract 2 (26.9 g) after solvent evaporation. Extract 1 was separated using gravity column chromatography over silica gel (Merck 9385) and a gradient solvent elution method, $\left(40 \mathrm{~cm}^{-3}, 63\right.$ fractions) using solvent mixtures of 50:50 hexane: $\mathrm{CH}_{2} \mathrm{Cl}_{2}\left(40 \mathrm{~cm}^{-3}, 6\right.$ fractions), 20:80 hexane: $\mathrm{CH}_{2} \mathrm{Cl}_{2}$ (40 $\mathrm{cm}^{-3}, 9$ fractions), $100 \% \mathrm{CH}_{2} \mathrm{Cl}_{2}\left(40 \mathrm{~cm}^{-3}, 4\right.$ 
fractions), 50:50 $\mathrm{CH}_{2} \mathrm{Cl}_{2}$ :EtOAc ( $40 \mathrm{~cm}^{-3}, 27$ fractions), 50:50 $\mathrm{CH}_{2} \mathrm{Cl}_{2}: \mathrm{MeOH}\left(20 \mathrm{~cm}^{-3}, 17\right.$ fractions). Fraction 24 yielded, after further purification, 30 (3.5 mg), Fractions $26-7$ yielded, after further purification $\mathbf{3 1}(139.5 \mathrm{mg})$ and $\mathbf{3 2}(1.9 \mathrm{mg})$. Fractions 34-38 yielded, after further purification 22 (101 mg), Fractions 41-43 yielded, after further purification $\mathbf{3 3}$ $(15.7 \mathrm{mg})$ and $\mathbf{3 4}(7.1 \mathrm{mg})$. Fraction 45 yielded, after further purification the previously unreported compound 35 (37.5 mg). Red-brown oil; [a $]^{27}$ D -55.6 (c 0.03, $\mathrm{CH}_{3} \mathrm{OH}$ ); ECD (c 0.03, MeOH) $290 \mathrm{~nm}(-5), 230 \mathrm{~nm}(-2) ; \mathrm{IR}(\mathrm{NaCl}) \nu_{\max } 3327,3007,2938,2400,2000$ $1668 \mathrm{~cm}^{-1} ;{ }^{1} \mathrm{H}$ NMR $\left(\mathrm{CDCl}_{3}, 500 \mathrm{MHz}\right),{ }^{13} \mathrm{C}$ NMR $\left(\mathrm{CDCl}_{3}, 125 \mathrm{MHz}\right)$ Table 3; HRESIMS $\mathrm{m} / \mathrm{z} 347.1125[\mathrm{M}+\mathrm{H}]^{+}\left(\right.$calcd for $\left[\mathrm{C}_{18} \mathrm{H}_{18} \mathrm{O}_{7}+\mathrm{H}^{+}, 347.1130\right)$

Extract 2 was separated using gravity column chromatography over silica gel (Merck 9385) and a gradient solvent elution method, $\left(40 \mathrm{~cm}^{-3}, 54\right.$ fractions $)$ using solvent mixtures of $100 \% \mathrm{CH}_{2} \mathrm{Cl}_{2}$ (40 $\mathrm{cm}^{-3}, 20$ fractions), 50:50 $\mathrm{CH}_{2} \mathrm{Cl}_{2}$ :EtOAc ( $40 \mathrm{~cm}^{-3}, 20$ fractions), 50:50 $\mathrm{CH}_{2} \mathrm{Cl}_{2}: \mathrm{MeOH}\left(20 \mathrm{~cm}^{-3}, 14\right.$ fractions $)$. Fractions 5-11 yielded after further purification 36 (1.5 mg). Fractions 31-33 yielded, after further purification, $37(1.2 \mathrm{mg}), \mathbf{3 8}(6.4 \mathrm{mg})$ and $\mathbf{3 9}$ $(1.2 \mathrm{mg})$. Compounds were identified using 2D NMR and CD methods and by comparison against literature data as referenced earlier.

Bulbs of E. bicolor ( $5 \mathrm{~kg}$ ) were chopped and extracted EtOH (3 L) for 48 hours. The EtOH extract was partitioned with $\mathrm{CH}_{2} \mathrm{Cl}_{2}(300 \mathrm{ml})$ yielding Extract $3(12.7 \mathrm{~g})$ after evaporation of the $\mathrm{CH}_{2} \mathrm{Cl}_{2}$ and the remaining EtOH extract, Extract $4(12.0 \mathrm{~g})$. The bulbs were re-extracted in 1-butanol (2.5 L) for 24 hours, yielding Extract 5 (14.8 g) after solvent evaporation. Extract $3(12.7 \mathrm{~g})$ was coated onto silica, loaded into a column and separated using flash column chromatography using a gradient solvent elution method, $\left(20 \mathrm{~cm}^{-3}, 282\right.$ fractions) using solvent mixtures of $100 \%$ hexane $\left(20 \mathrm{~cm}^{-3}, 50\right.$ fractions), 50:50 hexane: $\mathrm{CH}_{2} \mathrm{Cl}_{2}(20$ $\mathrm{cm}^{-3}, 50$ fractions), $100 \% \mathrm{CH}_{2} \mathrm{Cl}_{2}\left(20 \mathrm{~cm}^{-3}, 50\right.$ fractions), $50: 50 \mathrm{CH}_{2} \mathrm{Cl}_{2}:$ EtOAc $\left(20 \mathrm{~cm}^{-3}\right.$, 100 fractions), $50: 50 \mathrm{CH}_{2} \mathrm{Cl}_{2}: \mathrm{MeOH}\left(20 \mathrm{~cm}^{-3}, 32\right.$ fractions) Fractions $160-170$ yielded 40 (193.8 mg), Fractions 224-225 yielded 41 (321.9 mg). Extract 4 (12.0 g) was separated using gravity column chromatography over silica gel (Merck 9385) and a solvent mixture of $80: 20 \mathrm{CH}_{2} \mathrm{Cl}_{2}$ :EtOAc $\left(100 \mathrm{~cm}^{-3}, 9\right.$ fractions). Fraction 2 yielded 40 (60.5 mg), fractions 4-6 yielded 41 (322.7 mg). Extract 5 (14.8 g) was separated using gravity column chromatography over Sephadex using a solvent mixture of 50:50 50:50 $\mathrm{CH}_{2} \mathrm{Cl}_{2}: \mathrm{MeOH}(150$ $\mathrm{cm}^{-3}, 6$ fractions). Fractions 5-6 yielded, after further purification $41(186.7 \mathrm{mg})$ and 32 (28.2 mg). Compounds were identified using 2D NMR and CD methods and by comparison against literature data as referenced earlier.

\section{Synthesis of Compounds $42-50$.}

\section{Preparation of (E)-5,7-dimethoxy-3-(4'-methylthiobenzylidene)-4-chromanone}

(42): Under inert conditions, $\mathrm{NaH}$ (60\% in mineral oil, $13 \mathrm{mmol}$ ) was added to 3,5dimethoxyphenol $(1 \mathrm{~g}, 6 \mathrm{mmol})$ in dry $\operatorname{DMF}(10 \mathrm{~mL})$ at $10^{\circ} \mathrm{C}$. After stirring for 60 minutes, 3-bromopropionic acid (1.1 g, $7.2 \mathrm{mmol})$ was added and the reaction was further stirred at room temperature for 60 minutes. The mixture was acidified with $\mathrm{HCl}$ to $\mathrm{pH} 3-5$, extracted into EtOAc and washed with brine $(1 \times 30 \mathrm{~mL})$ and water $(1 \times 30 \mathrm{~mL})$. The product $(3-(3,5-$ dimethoxyphenoxy)-propanoic acid) was used without further purification. 
Polyphosphoric acid (10g) was added to 3-(3,5-dimethoxyphenoxy)-propanoic acid and the resulting mixture was heated at $80^{\circ} \mathrm{C}$ for 2 hours. The mixture was poured into ice water and extracted into diethyl ether. The extract was washed with $3 \mathrm{~N} \mathrm{NaOH}(30 \mathrm{~mL})$, water $(50 \mathrm{~mL})$ and dried over $\mathrm{MgSO}_{4}$. The product (3,5-dimethoxychromone) was heated at $80^{\circ} \mathrm{C}$ with 4methylthiobenzaldehyde (1:1 molar equivalent) and piperidine (4-5 drops) and the reaction was monitored by tlc (3:7, EtOAc: $n$-hexane). The mixture was diluted with water and extracted into EtOAc. This was washed with water $(30 \mathrm{~mL})$ and brine $(30 \mathrm{~mL})$, before drying over $\mathrm{MgSO}_{4}$. The resulting product was purified by flash column chromatography (3:7, EtOAc: $n$-hexane) to give (E)-5,7-dimethoxy-3-(4'-methylthiobenzylidene)-4chromanone (42) as a yellow gum (61 mg, 3.0\% overall yield).

UV (MeOH) $\lambda_{\max }(\log \varepsilon) 346$ (-3.78); IR (ATR) $\nu_{\max } 1659,1583,1495,1463,1343,1198$, 1093, $830 \mathrm{~cm}^{-1} ;{ }^{1} \mathrm{H}$ NMR $\left(\mathrm{CDCl}_{3}, 400 \mathrm{MHz}\right)$ Table $4 ;{ }^{13} \mathrm{C}$ NMR $\left(\mathrm{CDCl}_{3}, 100 \mathrm{MHz}\right)$ Table 5; HRESIMS $m / z 343.0989[\mathrm{M}+\mathrm{H}]^{+}\left(\right.$calcd for $\left.\left[\mathrm{C}_{19} \mathrm{H}_{18} \mathrm{O}_{4} \mathrm{SH}+\mathrm{H}\right]^{+}, 343.0999\right)$

Preparation of (E)-7,8-dimethoxy-3-(4'-methylthiobenzylidene)-4-chromanone (43): Under inert conditions, $\mathrm{NaH}$ (60\% in mineral oil, $13 \mathrm{mmol}$ ) was added to 2,3dimethoxyphenol $(1 \mathrm{~g}, 6 \mathrm{mmol})$ in dry $\operatorname{DMF}(10 \mathrm{~mL})$ at $10^{\circ} \mathrm{C}$. After stirring for 60 minutes, 3-bromopropionic acid (1.1 g, $7.2 \mathrm{mmol})$ was added and the reaction was further stirred at room temperature for 60 minutes. The mixture was acidified with $\mathrm{HCl}$ to $\mathrm{pH} 3-5$, extracted into EtOAc and washed with brine $(1 \times 30 \mathrm{~mL})$ and water $(1 \times 30 \mathrm{~mL})$. The product $(3-(2,3-$ dimethoxyphenoxy)-propanoic acid) was used without further purification.

Polyphosphoric acid (10g) was added to 3-(2,3-dimethoxyphenoxy)-propanoic acid (from above) and the resulting mixture was heated at $80^{\circ} \mathrm{C}$ for 2 hours. The mixture was poured into ice water and extracted into diethyl ether. The extract was washed with $3 \mathrm{~N} \mathrm{NaOH}(30$ $\mathrm{mL})$, water $(50 \mathrm{~mL})$ and dried over magnesium sulphate. The product $(2,3-$ dimethoxychromone) was heated at $80^{\circ} \mathrm{C}$ with 4-methylthiobenzaldehyde (1:1 molar equivalent) and piperidine (4-5 drops) and the reaction was monitored by tlc (3:7, EtOAc: $n-$ hexane). The mixture was diluted with water and extracted into EtOAc, washed with water $(30 \mathrm{~mL})$ and brine $(30 \mathrm{~mL})$, before drying over $\mathrm{MgSO}_{4}$. The product was purified by flash column chromatography (3:7, EtOAc: $n$-hexane) to give (E)-7,8-dimethoxy-3-(4'methylthiobenzylidene)-4-chromanone (43) as a yellow gum (72 $\mathrm{mg}, 3.5 \%$ overall yield).

UV (MeOH) $\lambda_{\max }(\log \varepsilon) 343$ (-4.02); IR (NaCl) $\nu_{\max } 2921,1665,1580,1572,1493,1425$, 1306, 1264, 1159, $820 \mathrm{~cm}^{-1} ;{ }_{1} \mathrm{H}$ NMR $\left(\mathrm{CDCl}_{3}, 400 \mathrm{MHz}\right)$ Table $4 ;{ }^{13} \mathrm{C} \mathrm{NMR}\left(\mathrm{CDCl}_{3}, 100\right.$ $\mathrm{MHz}$ ) Table 5; HRESIMS $\mathrm{m} / \mathrm{z} 343.0995[\mathrm{M}+\mathrm{H}]^{+}\left(\right.$calcd for $\left[\mathrm{C}_{19} \mathrm{H}_{18} \mathrm{O}_{4} \mathrm{SH}+\mathrm{H}\right]^{+}$, 343.0999)

\section{Preparation of (E)-5,6,7-trimethoxy-3-(3'-hydroxy-4'-methoxybenzylidene)-4-} chromanone (44): Under inert conditions, $\mathrm{NaH}(60 \%$ in mineral oil, $13 \mathrm{mmol})$ was added to 3,4,5-trimethoxyphenol $(1 \mathrm{~g}, 5.4 \mathrm{mmol})$ in dry DMF $(10 \mathrm{~mL})$ at $10^{\circ} \mathrm{C}$. After stirring for 60 minutes, 3-bromopropionic acid $(1.1 \mathrm{~g}, 7.2 \mathrm{mmol})$ was added and the reaction was further stirred at room temperature for 60 minutes. The mixture was diluted with methanol $(20 \mathrm{ml})$ acidified with $\mathrm{HCl}$ to $\mathrm{pH} 3-5$, extracted into EtOAc and washed with brine $(1 \times 30 \mathrm{~mL})$ and 
water $(1 \times 30 \mathrm{~mL})$. The product (3-(3,4,5-trimethoxyphenoxy)-propanoic acid) was used without further purification.

Polyphosphoric acid (10 g) was added to 3-(3,4,5-trimethoxyphenoxy)-propanoic acid (from above) and the resulting mixture was heated at $80^{\circ} \mathrm{C}$ for 2 hours. The mixture was poured into ice water and extracted into diethyl ether. The extract was washed with $3 \mathrm{M} \mathrm{NaOH}(30$ $\mathrm{mL})$, water $(50 \mathrm{~mL})$ and dried over $\mathrm{MgSO}_{4}$. The product (3,4,5-trimethoxychromone) was heated at $80^{\circ} \mathrm{C}$ with 3-hydroxy-4-methoxybenzaldehyde (1:1 molar equivalent) and piperidine (4-5 drops) and the reaction was monitored by tlc (3:7, EtOAc: $n$-hexane). The mixture was diluted with water and extracted into EtOAc, washed with water $(30 \mathrm{~mL})$ and brine $(30 \mathrm{~mL})$, before drying over $\mathrm{MgSO}_{4}$. The resultant product was purified by flash column chromatography (3:7, EtOAc: $n$-hexane) to give $(E)-5,6,7$-trimethoxy-3-(3' hydroxy-4'-methoxybenzylidene)-4-chromanone (44) as a yellow gum $(0.1053 \mathrm{~g}, 5.2 \%$ yield).

UV (MeOH) $\lambda_{\max }(\log \varepsilon) 360$ (-3.77), 348 (-3.76), IR $\nu_{\max }(\mathrm{NaCl}) 3650-3590,3376,2936$, 2841, $1596 \mathrm{~cm}^{-1}$; ${ }^{1} \mathrm{H}$ NMR $\left(\mathrm{CDCl}_{3}, 400 \mathrm{MHz}\right)$ Table $4 ;{ }^{13} \mathrm{C}$ NMR $\left(\mathrm{CDCl}_{3}, 100 \mathrm{MHz}\right)$ Table 5 ; HRESIMS $m / z 395.1096[\mathrm{M}+\mathrm{Na}]^{+}\left(\right.$calcd for $\left.\left[\mathrm{C}_{20} \mathrm{H}_{20} \mathrm{O}_{7}+\mathrm{Na}\right]^{+}, 395.1107\right)$

Preparation of 5,6,7-trimethoxy-3(R)-(3'hydroxy-4'-methoxybenzyl)-4chromanone (45): Compound 44 (34.6mg, 0.093mmol) was dissolved in deuterated toluene (1 mL). Iridium catalyst 1, $(S)$-(-)-2-[2-(diphenylphosphino)phenyl]-4-isopropyl-2oxazolium-(1,5)-cyclooctadiene iridium (I) tetrakis(3,5-bis(trifluoromethyl)phenyl borate (Scheme 2) was added (1\%) and the reactor was pressurised to 5 bar with hydrogen. The reaction was stirred overnight at room temperature. The mixture was filtered to remove the catalyst and the NMR data were obtained directly in deuterated toluene (quantitative yield).

Yellow gum; $[\mathrm{a}]^{23} \mathrm{D}-43.8$ (c 0.9, $\left.\mathrm{CH}_{3} \mathrm{OH}\right)$; ECD (c 0.03, ACN) $326 \mathrm{~nm}(+1.3), 284 \mathrm{~nm}$ $(-1.9) \mathrm{UV}(\mathrm{MeOH}) \lambda_{\max }(\log \varepsilon) 277(-4.20), 277(-3.66)$; IR $(\mathrm{NaCl}) \nu_{\max } 2936,1674$, 1580, 1567, 1485, 1454, 1412, 1200, 1179, 1116, $822 \mathrm{~cm}^{-1} ;{ }^{1} \mathrm{H} \mathrm{NMR}\left(\mathrm{CDCl}_{3}, 400 \mathrm{MHz}\right)$ Table 4; ${ }^{13} \mathrm{C}$ NMR $\left(\mathrm{CDCl}_{3}, 100 \mathrm{MHz}\right)$ Table 5; HRESIMS $\mathrm{m} / z 397.1259[\mathrm{M}+\mathrm{Na}]^{+}($calcd for $\left[\mathrm{C}_{20} \mathrm{H}_{22} \mathrm{O}_{7}+\mathrm{Na}\right]^{+}, 397.1263$ )

\section{Preparation of 5,6,7-trimethoxy-3-(3'hydroxy-4'-methoxybenzyl)-chromane} (46): Compound 44 (50.0 mg, $0.134 \mathrm{mmol})$ was dissolved in methanol (2 mL). Pd/C (10\%) was added, the flask was saturated with $\mathrm{H}_{2}$ (1 atmosphere) and the mixture was stirred overnight at room temperature. The catalyst was filtered and the solvent removed under reduced pressure to yield $\mathbf{4 6}$ (quantitative yield).

Yellow gum; UV (MeOH) $\lambda_{\max }(\log \varepsilon) 282(-3.14) ;{ }^{1} \mathrm{H}$ NMR $\left(\mathrm{CDCl}_{3}, 400 \mathrm{MHz}\right)$ Table 4; ${ }^{13} \mathrm{C} \mathrm{NMR}\left(\mathrm{CDCl}_{3}, 100 \mathrm{MHz}\right)$ Table 5; HRESIMS $\mathrm{m} / z 383.1462[\mathrm{M}+\mathrm{Na}]^{+}$(calcd for $\left.\left[\mathrm{C}_{20} \mathrm{H}_{24} \mathrm{O}_{6}+\mathrm{Na}\right]^{+}, 383.1471\right)$

Preparation of 5,6,7-trimethoxy-3-(3'hydroxy-4'-methoxybenzyl)-4chromanone (47): Compound 44 (5.9 mg, $0.0158 \mathrm{mmol})$ was dissolved in toluene (2 $\mathrm{mL})$. Wilkinson's catalyst (1\%) was added, the flask was saturated with $\mathrm{H}_{2}$ (1 atmosphere) and 
the mixture was stirred overnight at room temperature. The catalyst was filtered and the solvent removed under reduced pressure. The mixture obtained was subject to column chromatography over silica gel (8:2 EtOAc: $\mathrm{CH}_{2} \mathrm{Cl}_{2}$ ) to yield $\mathbf{4 7}$ (2.4 mg, $40 \%$ yield). Yellow gum; UV (MeOH) $\lambda_{\max }(\log \varepsilon) 278(-3.02) ;{ }^{1} \mathrm{H} \mathrm{NMR}\left(\mathrm{CDCl}_{3}, 400 \mathrm{MHz}\right)$ Table 4; HRESIMS m/z $397.1254[\mathrm{M}+\mathrm{Na}]^{+}\left(\right.$calcd for $\left.\left[\mathrm{C}_{20} \mathrm{H}_{22} \mathrm{O}_{7}+\mathrm{Na}\right]^{+}, 397.1263\right)$.

\section{Preparation of (E)-5-hydroxy-6,7-trimethoxy-3-(3'hydroxy-4'-} methoxybenzylidene)-4-chromanone (48): Compound 44 (7.9 $\mathrm{mg}, 0.021 \mathrm{mmol}$ ) was dissolved in dry $\mathrm{CH}_{2} \mathrm{Cl}_{2}(2 \mathrm{~mL})$ and cooled to $0^{\circ} \mathrm{C}$. TMSCl (8 equivalents) and $\mathrm{NaI}$ ( 8 equivalents) were added and the mixture was heated to $60^{\circ} \mathrm{C}$ for 2 hours. The solvent was removed under reduced pressure and the product purified using column chromatography over silica gel (2:8, EtOAc: $\left.\mathrm{CH}_{2} \mathrm{Cl}_{2}\right)$ to give 5-hydroxy-6,7-trimethoxy-3-(3'hydroxy-4'methoxybenzylidene)-4-chromanone (48) (4.5 $\mathrm{mg}, 60 \%$ yield).

Yellow gum; UV (MeOH) $\lambda_{\max }(\log \varepsilon) 368(-4.03)$; IR (NaCl) $v_{\max } 3525,2935,2848$, $1643,1579,1511,1455,1359,1272,1202,1106,813,736 \mathrm{~cm}^{-} 1 ;{ }^{1} \mathrm{H}$ NMR $\left(\mathrm{CDCl}_{3}, 400\right.$ MHz) Table 4; ${ }^{13} \mathrm{C}$ NMR $\left(\mathrm{CDCl}_{3}, 100 \mathrm{MHz}\right)$ Table 5; HRESIMS m/z $381.0946[\mathrm{M}+\mathrm{Na}]^{+}$ (calcd for $\left[\mathrm{C}_{19} \mathrm{H}_{18} \mathrm{O}_{7}+\mathrm{Na}\right]^{+}, 381.0950$ ).

Preparation of (E)-5,6,7-trimethoxy-3-(4'- chloro-3'- hydroxybenzylidene)-4chromanone (49): $\mathrm{NaH}$ (60\% in mineral oil, $13 \mathrm{mmol}$ ) was added to 3,4,5trimethoxyphenol $(1 \mathrm{~g}, 5.4 \mathrm{mmol})$ in dry $\operatorname{DMF}(10 \mathrm{~mL})$ at $10^{\circ} \mathrm{C}$ under inert conditions. After stirring for 60 minutes, 3-bromopropionic acid $(1.1 \mathrm{~g}, 7.2 \mathrm{mmol})$ was added and the reaction was stirred at room temperature for a further 60 minutes. The mixture was acidified with $\mathrm{HCl}$ to $\mathrm{pH} 3-5$, extracted into EtOAc and washed with brine $(1 \times 30 \mathrm{~mL})$ and water $(1 \times 30$ $\mathrm{mL}$ ). The product (3-(3,4,5-trimethoxyphenoxy)-propanoic acid) was used without further purification.

Polyphosphoric acid (10 g) was added to 3-(3,4,5-trimethoxyphenoxy)-propanoic acid (from above) and the resulting mixture was heated at $80^{\circ} \mathrm{C}$ for 2 hours. The mixture was poured into ice water and extracted with diethyl ether. The extract was washed with $3 \mathrm{M} \mathrm{NaOH}(30$ $\mathrm{mL})$, water $(50 \mathrm{~mL})$ and dried over magnesium sulphate. The product $(3,4,5-$ trimethoxychromone) was heated at $80^{\circ} \mathrm{C}$ with 4-chloro-3-hydroxybenzaldehyde (1:1 molar equivalent) and piperidine (4-5 drops) and the reaction was monitored by tlc (3:7, EtOAc: $n$ hexane) and was found to be complete after 24 hours. The mixture was diluted with water and extracted into EtOAc, then washed with water $(30 \mathrm{~mL})$ and brine $(30 \mathrm{~mL})$, before drying over $\mathrm{MgSO}_{4}$. The product was purified by flash column chromatography (3:7, EtOAc:nhexane) to give 5,6,7-trimethoxy-3-(4'-chloro-3' - hydroxybenzylidene)-4-chromanone (49) as a yellow powder $(155 \mathrm{mg}, 7.8 \%$ yield $)$.

UV (MeOH) $\lambda_{\max }(\log \varepsilon) 295$ (-3.94), $352(-3.77)$; IR (NaCl) $\nu_{\max } 3328,2939,1661$, $1650,1488,1470,1415,1391,1258,1201,1171,1100,818 \mathrm{~cm}^{-1} 1{ }^{1} \mathrm{H} \mathrm{NMR}\left(\mathrm{CDCl}_{3}, 400\right.$ MHz) Table 4; ${ }^{13} \mathrm{C} \mathrm{NMR}\left(\mathrm{CDCl}_{3}, 100 \mathrm{MHz}\right)$ Table 5; HRESIMS m/z 377.0786 [M + H] ${ }^{+}$ [calcd for $\left(\mathrm{C}_{19} \mathrm{H}_{17} \mathrm{O}_{6} \mathrm{Cl}+\mathrm{H}\right)^{+}, 377.0792$ ] 
Preparation of (E)-3-(3,4-dimethoxylphenyl)-1-(4-ethoxy-2-hydroxy-3-methylphenyl)prop-2-en-1-one (50): 4-Ethoxy-2-hydroxy-3-methyl acetophenone (0.1 g, 0.51 mmol) was added to 3,4-dimethoxybenzaldehyde $(0.85 \mathrm{~g}, 0.51 \mathrm{mmol})$ and $10 \% \mathrm{NaOH}(1$ $\mathrm{mL})$ in methanol (5 ml) and stirred at room temperature for 2 hours. Upon standing, $(E)$-3(3,4-dimethoxylphenyl)-1-(4-ethoxy-2-hydroxy-3-methyl-phenyl)prop-2-en-1-one (50) precipitated out as a yellow powder and was isolated by vacuum filtration $(25.9 \mathrm{mg}, 15 \%$ yield).

$\mathrm{UV}(\mathrm{MeOH}) \lambda_{\max }(\log \varepsilon) 368$ (-4.62); IR (ATR) $v_{\max } 1650,1570,1550,1499,1419,1364$, $1265,1221,1080,847 \mathrm{~cm}^{-1} ;{ }_{1} \mathrm{H}$ NMR $\left(\mathrm{CDCl}_{3}, 400 \mathrm{MHz}\right)$ Table $4 ;{ }^{13} \mathrm{C} \mathrm{NMR}\left(\mathrm{CDCl}_{3}, 100\right.$ MHz) Table 5; HRESIMS $m / z 343.1545$ [M + H] ${ }^{+}$[calcd for $\left(\mathrm{C}_{20} \mathrm{H}_{22} \mathrm{O}_{5}+\mathrm{H}\right)^{+}, 343.1545$ ].

\section{Biological Methods}

Materials-Human retinal microvascular endothelial cells (HRECs; Cell Systems, Seattle, WA) and human umbilical vein endothelial cells (HUVECs; Lonza, Walkersville, MD), were used between passage 5 and 8. Endothelial Growth Medium (EGM-2) was prepared by mixing the contents of an EGM-2 "Bullet Kit" (Cat no. CC-4147) with Endothelial Basal Medium (EBM) (Cat no. CC-3156) (Lonza). 92-1 uveal melanoma cells (a kind gift of Dr. Martine Jager, University of Leiden) were grown in RPMI medium containing 10\% FBS and $1 \%$ penicillin-streptomycin (pen-strep). Y-79 retinoblastoma cells (a kind gift of Dr. Brenda L. Gallie, Ontario Cancer Institute) were grown in RB medium (IMDM + 10\% FBS + 55 $\mu \mathrm{M} \beta$-mercaptoethanol $+10 \mu \mathrm{g} / \mathrm{mL}$ Insulin $+1 \%$ pen-strep). ARPE-19 retinal pigment epithelial cells (ATCC, Manassas, VA) were grown in DMEM containing 10\% FBS and 1\% pen-strep. AlamarBlue reagent (product code BUF012B) was from AbD Serotec (Raleigh, NC). Matrigel matrix basement membrane (Cat no.354234) was purchased from Corning (Corning, NY)

Cell proliferation assay: The antiproliferative activities of different compounds were monitored by an alamarBlue based fluorescence assay as described previously. ${ }^{43}$ Five cell types were used: the target endothelial cell type (HRECs), a non-target endothelial cell type (HUVECs), a non-target normal retinal pigment epithelial cell line (ARPE-19), a non-target uveal melanoma cell line (92-1), and a non-target retinoblastoma cell line (Y79). Briefly, 2,500 cells in $100 \mu \mathrm{L}$ growth medium were incubated in 96-well clear bottom black plates for 24 hours at $37^{\circ} \mathrm{C}, 5 \% \mathrm{CO}_{2}$, different concentrations of each test compound were then added (range: $0.5 \mathrm{nM}$ to $500 \mu \mathrm{M}$ ) followed by 44 hours incubation. $11.1 \mu \mathrm{L}$ of alamarBlue reagent was then added and after 4 hours, fluorescence readings were taken on a Synergy H1 plate reader (Biotek, Winooski, VT) with excitation and emission wavelengths of $560 \mathrm{~nm}$ and $590 \mathrm{~nm}$ respectively. GraphPad Prism software (v. 7.0) was used for data analysis. Compounds that reduced cell number by $50 \%$ or more at the highest concentration tested (relative to DMSO control) were reported as having a $\mathrm{GI}_{50}<100 \mu \mathrm{M}$.

In vitro tube formation assay: A Matrigel based tube formation assay was performed to monitor the ability of HRECs to form tube-like structures in the presence of different concentrations of $\mathbf{1 3}, \mathbf{2 7}, \mathbf{2 8}, \mathbf{4 5}, \mathbf{4 6}, \mathbf{4 8}$ and $\mathbf{5 0}$, as described previously. ${ }^{20}$ Briefly, 15,000 cells in $100 \mu \mathrm{L}$ EGM-2 medium were incubated in the absence (DMSO treated) and 
presence of different concentrations of each compound in 96-well clear plates coated with $50 \mu \mathrm{L}$ of Matrigel basement membrane. Known antiangiogenic homoisoflavonoid SH-1 $1037^{21}$ was a positive control. After 8 hours, the images were recorded using an EVOS FL microscope (AMG, Mill Creek, WA) and the tube length was measured using Angiogenesis Analyzer macros in ImageJ (http://image.bio.methods.free.fr/ImageJ/? Angiogenesis-Analyzer-for-ImageJ).

Statistical analysis: The data obtained from tube formation experiments were analyzed by one-way ANOVA with Dunnett's post hoc tests for comparisons between compounds' treatments and control. All analyses were performed using GraphPad Prism software (v.7.0). A $p$ value of $<0.05$ was considered statistically significant.

\section{Supplementary Material}

Refer to Web version on PubMed Central for supplementary material.

\section{ACKNOWLEDGEMENTS}

H. Whitmore acknowledges a PhD scholarship from the University of Surrey. Sianne Schwikkard acknowledges support from the Daphne Jackson Trust, the University of Surrey and the Royal Society of Chemistry for funding. T. W. Corson acknowledges support from NIH/NEI R01EY025641, the International Retinal Research Foundation, and an unrestricted grant from Research to Prevent Blindness, Inc. Sianne Schwikkard would also like to acknowledge and thank the EPSRC UK National Mass Spectrometry Facility, Swansea for HRMS analysis.

\section{References}

(1). Penn JS; Madan A; Caldwell RB; Bartoli M; Caldwell RW; Hartnett M Prog. Retin. Eye Res 2008, 27, 331-371. [PubMed: 18653375]

(2). Zhang SX; Ma JX Prog. Retin. Eye Res 2007, 26, 1-37. [PubMed: 17074526]

(3). Folk JC; Stone EM N. Engl. J. Med 2010, 363, 1648-1655. [PubMed: 20961248]

(4). Stewart MW Mayo Clin. Proc 2012, 87, 77-88. [PubMed: 22212972]

(5). Falavarjani KG; Nguyen QD Eye (Lond) 2013, 27, 787-794. [PubMed: 23722722]

(6). Lux A; Llacer H; Heussen FM; Joussen AM Br. J. Ophthalmol 2007, 91, 1318-1322. [PubMed: 17537784]

(7). Sulaiman RS; Basavarajappa HD; Corson TW Exp. Eye Res 2014, 129, 161-171. [PubMed: 25304218]

(8). Lin LG; Liu QY; Ye Y Planta Med 2014, 80, 1053-1066. [PubMed: 25153098]

(9). Mulholland DA; Schwikkard SL; Crouch NR Nat. Prod. Rep 2013, 30, 1153-1266.

(10). Pohl TS; Crouch NR; Mulholland DA Curr. Org. Chem 2000, 4, 1287-1324.

(11). Moodley N; Crouch NR; Mulholland DA; Slade D; Ferreira D, S. Afr. J. Bot 2006, 72, 517-520.

(12). Sparg SG; van Staden J; Jager AK J. Ethnopharmacol 2002, 80, 95-101. [PubMed: 11891092]

(13). Crouch NR; Bangani V; Mulholland DA Phytochem 1999, 51, 943-946.

(14). Shim JS; Kim JH; Lee J; Kim SN; Kwon HJ Planta Med 2004, 70, 171-173. [PubMed: 14994197]

(15). Kim JH; Kim KH; Yu YS; Kim YM; Kim KW; Kwon HJ Biochem. Biophys. Res. Commun 2007, 362, 848-852. [PubMed: 17803958]

(16). Kim JH; Yu YS; Jun HO; Kwon HJ; Park KH; Kim KW Mol. Vis 2008, 14, 556-561. [PubMed: 18385791]

(17). Adinolfi M; Corsaro MM; Lanzetta R; Laonigro G; Mangoni L; Parrilli M Phytochem, 1986, 26, 285-290. 
(18). Lee B; Basavarajappa HD; Sulaiman RS; Fei X; Seo SY; Corson TW Org. Biomol. Chem 2014, 12, 7673-7677. [PubMed: 25167470]

(19). Basavarajappa HD; Lee B; Fei X; Lim D; Callaghan B; Mund JA; Case J; Rajashekhar G; Seo SY; Corson TW PLoS One 2014, 9, e95694. [PubMed: 24752613]

(20). Basavarajappa HD; Lee B; Lee H; Sulaiman RS; An H; Magana C; Shadmand M; Vayl A; Rajashekhar G; Kim EY; Suh YG; Lee K; Seo SY; Corson TW J. Med. Chem 2015, 58, 50155027. [PubMed: 26035340]

(21). Sulaiman RS; Merrigan S; Quigley J; Qi X; Lee B; Boulton ME; Kennedy B; Seo SY; Corson TW Sci. Rep 2016, 6, 25509. [PubMed: 27148944]

(22). Schwikkard SL; Whitmore H; Corson TW; Sishtla K; Langat MK; Carew M Mulholland DA Planta Med 2018, DOI: 10.1055/a-0577-5322

(23). Waller CP; Thumser AE; Langat MK; Crouch NR; Mulholland DA Phytochem 2013, 95, 284 290.

(24). Schwikkard S; Alqahtani A; Knirsch W; Wetschnig W; Jaksevicius A; Opara EI; Langat MK; Andriantiana JL; Mulholland DA J. Nat. Prod 2017, 80, 30-37. [PubMed: 28051316]

(25). Corsaro MM; Lanzetta R; Mancino A; Parrilli M Phytochem 1992, 31, 1395-1397.

(26). Boehler P; Tamm CH; Tetrahedron Lett 1967, 8, 3479-3483.

(27). Tamm CH Arzneimittel-Forschung 1972, 22, 1776-1784. [PubMed: 4677071]

(28). Sidwell WTL; Tamm CH Tetrahedron Lett 1970, 7, 475-478.

(29). Farkas L; Gottsegen A; Nogradi M; Strelisky J Tetrahedron, 1971, 27, 5049-5056.

(30). Sihra JK; Mulholland DA; Langat MK; Crouch NR; Nuzillard J-M RSC Advances, 2017, 7, 15416-15427.

(31). Finckh RE; Tamm CH Experientia, 1970, 26, 472-473. [PubMed: 5444814]

(32). Koorbanally NA; Crouch NR; Harilal A; Pillay B; Mulholland DA Biochem. Syst. and Ecology, 2006, 34, 114-118.

(33). Ghoran S; Ebrahimi P; Mighani H; Saeidnia S, Braz. J. Pharm. Sci, 2015, 51, 949-955.

(34). Alali F; El-Elimat T; Albataineh H; Al-Balas Q; Al-Gharaibeh M; Falkinham J; Chen W; Swanson S; Oberlies N, J. Nat. Prod, 2015, 78, 1708-15. [PubMed: 26147490]

(35). Adinolfi M; Barone G; Belardini M; Lanzetta R; Laonigro G; Parrilli M, Phytochemistry, 1985, 23, 2091-2093.

(36). Shaik MM; Kruger HG; Bodenstein J; Smith P; du Toit K Nat. Prod. Res, 2014, 26, 1473-1482.

(37). Lu S-M; Bolm C Angew. Chem. Int. Ed, 2008, 47, 8920-8923.

(38). Sharma P; Kumar S; Ali F; Anthal S; Gupta VK; Khan IA; Singh S; Sangwan PL; Suri KA; Gupta DK; Dutt P; Vishwakarma RA; Satti N Med. Chem. Res, 2013, 22, 3969-3983.

(39). Corson TW; Basavarajappa HD; Seo S-Y; Lee B; Fei X Indiana University Research and Technology Corporation; Gachon University of Industry Academic Cooperation Foundation; W02014/182695, 2014, A1I.

(40). Nugroho AE; Morita H, J. Nat. Med, 2014, 68, 1-10. [PubMed: 23564068]

(41). Aziz AN; Ismail NH; Halim SNA; Looi CY; Anouar EH; Langat MK; Mulholland D; Awang K, Laevifins A-G, Phytochemistry, 2018, 156, 193-200. [PubMed: 30316148]

(42). Adinolfi M; Barone G; Corsaro MM; Mangoni L; Lanzetta R; Parrilli M, Tetrahedron, 1988, 44, 4981-4988.

(43). Arnaoutova I; Kleinman HK Nat. Protoc, 2010, 5, 628-635. [PubMed: 20224563]

(44). Basavarajappa HD; Sulaiman RS; Qi X; Shetty T; Sheik PBS; Sishtla KL; Lee B; Quigley J; Alkhairy S; Briggs CM; Gupta K; Tang B; Shadmand M; Grant MB; Boulton ME; Seo SY; Corson TW EMBO Mol Med 2017, 9, 786-801. [PubMed: 28377496]

(45). Sulaiman RS; Park B; Sheik PBS; Si Y; Kharwadkar R; Mitter SK; Lee B; Sun W; Qi X; Boulton ME; Meroueh SO; Fei X; Seo SY; Corson TW ACS Chem Biol, 2017, 13, 45-52. [PubMed: 29193961]

(46). Liao LX; Song XM; Wang LC; Lv HN; Chen JF; Liu D; Fu G; Zhao MB; Jiang Y; Zeng KW; Tu PF; Proc Natl Acad Sci USA, 2017, 114, E5986-E5994. [PubMed: 28674004] 


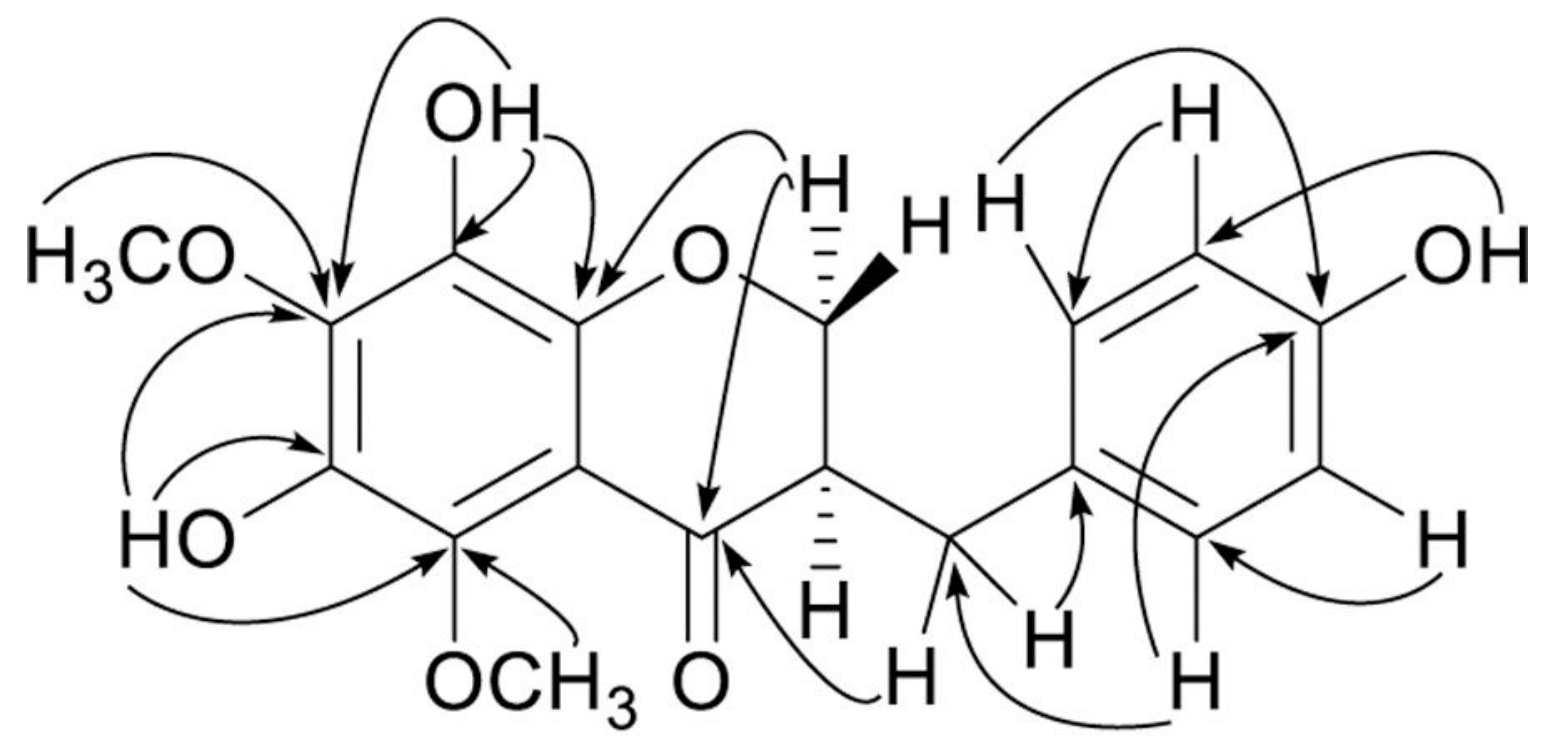

\section{5}

Figure 1.

HMBC correlations $(\mathrm{H} \rightarrow \mathrm{C}$ ) for compound 35 . 

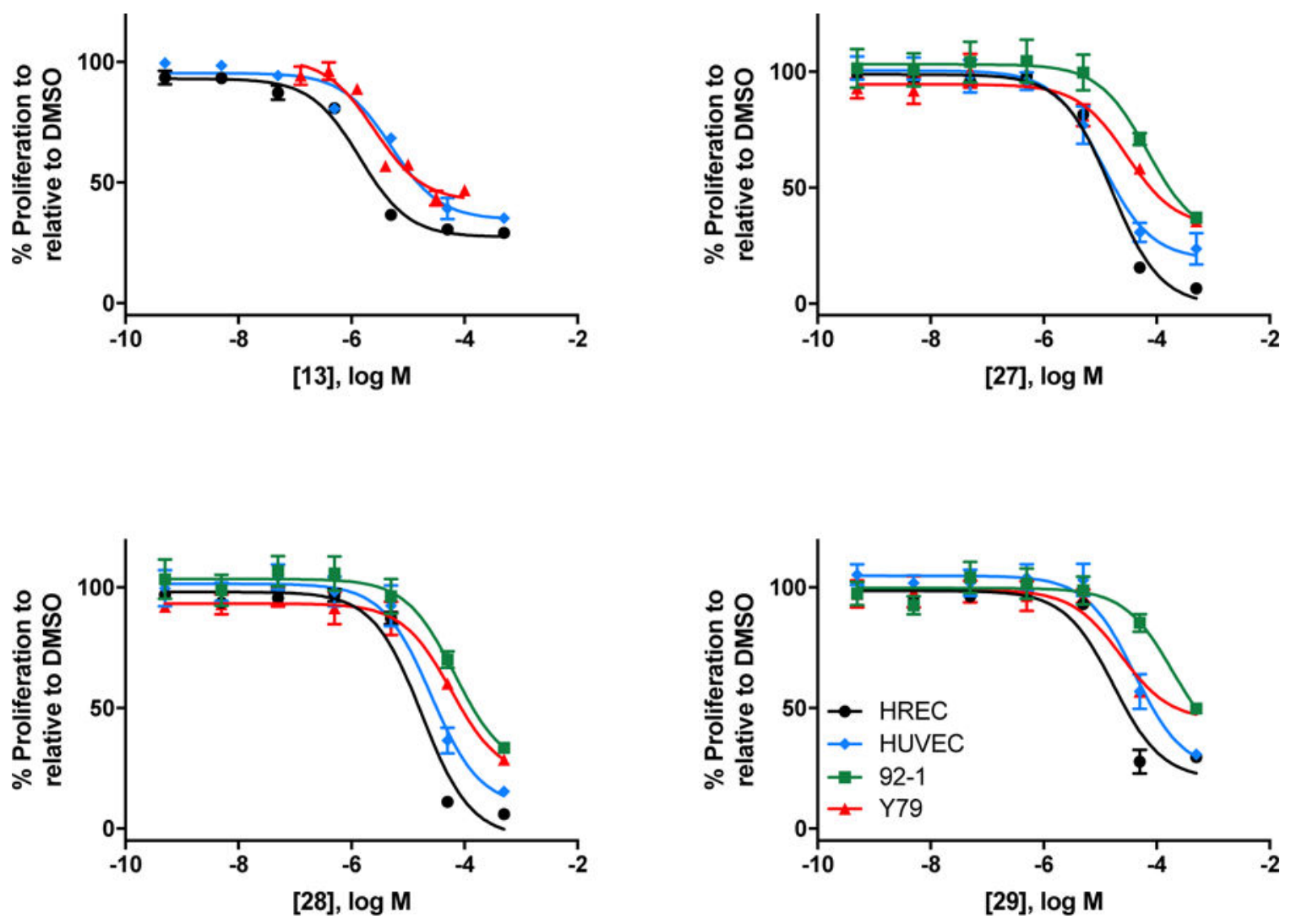

Figure 2.

Homoisoflavonoids block the proliferation of HRECs. Dose-response curves for representative active compounds' effects on proliferation of the indicated cell types as assessed by alamarBlue fluorescence. Mean \pm SEM, $n=3-6$ wells. 


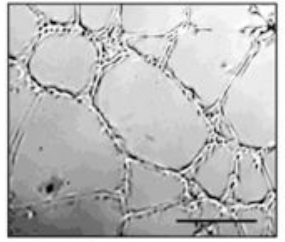

DMSO

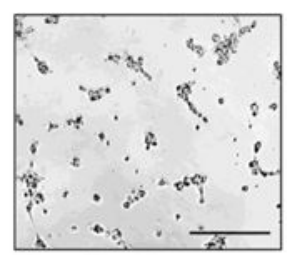

$13100 \mu \mathrm{M}$

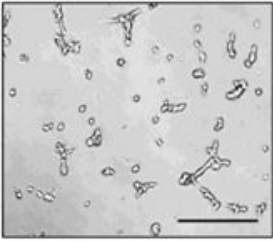

$27100 \mu \mathrm{M}$

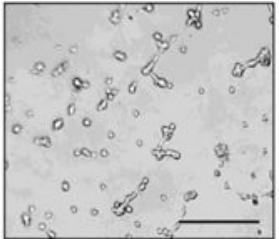

$2810 \mu \mathrm{M}$
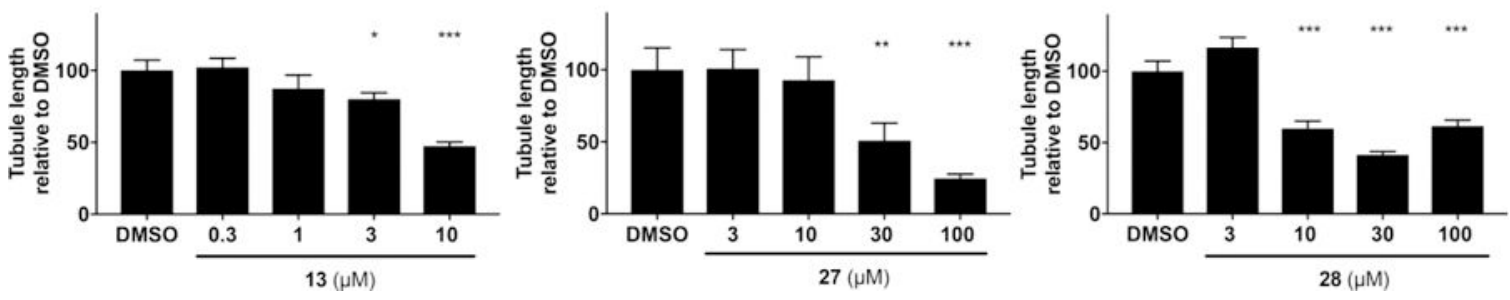

Figure 3.

Potent natural-source homoisoflavonoids significantly block the ability of HRECs to form tube-like structures. Top, Representative images of the tube formation of HRECs on Matrigel at the highest concentrations of each compound tested plus DMSO control, scale bars $=250 \mu \mathrm{m}$. Bottom, Quantification of the extent of tube formation was measured as tubule length of HRECs treated with compounds compared to DMSO control. Mean \pm SEM, $\mathrm{n}=3-6$ wells. Representative results from duplicate experiments. $* \mathrm{P}<0.05, * * * \mathrm{P}<0.001$ compared to DMSO control (One-way ANOVA with Dunnett's post-hoc tests). 


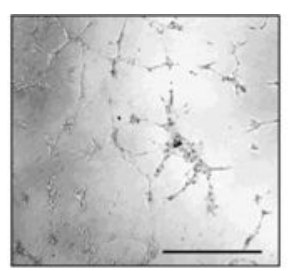

DMSO

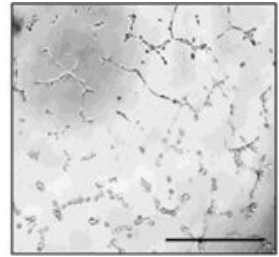

$450.1 \mu \mathrm{M}$

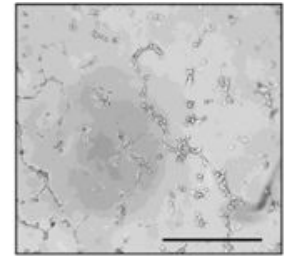

$480.5 \mu \mathrm{M}$

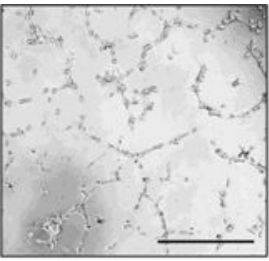

$505 \mu \mathrm{M}$

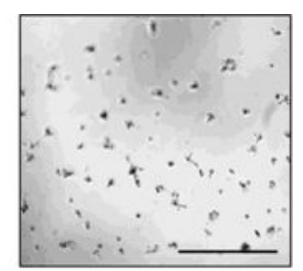

$\mathrm{SH}-110370.5 \mu \mathrm{M}$

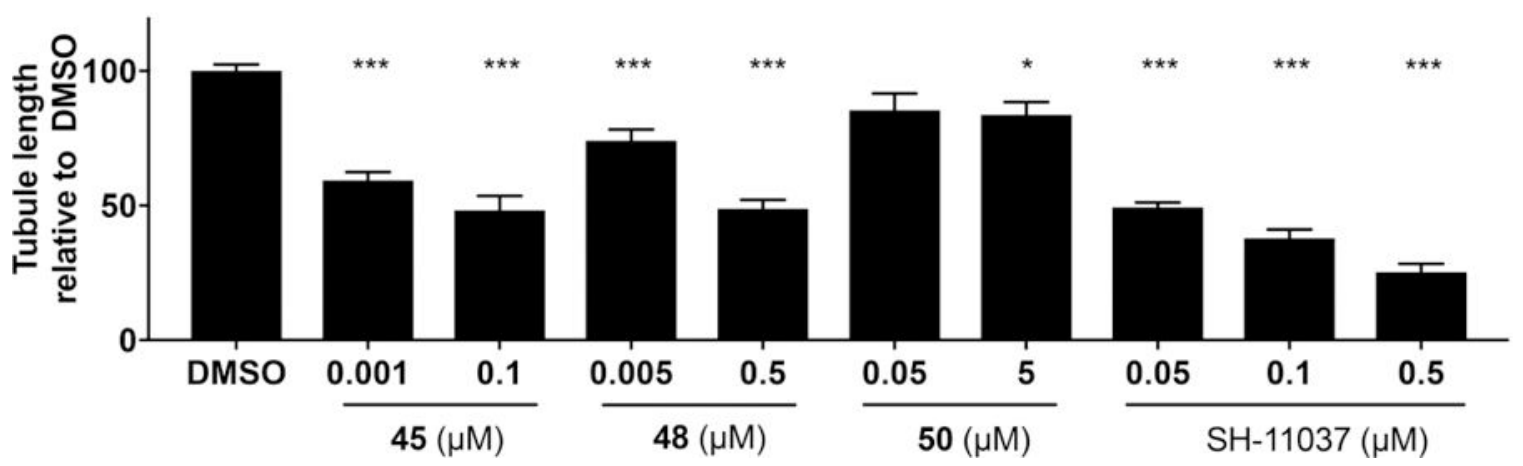

Figure 4.

Potent synthetic homoisoflavonoids significantly block the ability of HRECs to form tubelike structures. Top, Representative images of the tube formation of HRECs on Matrigel at the highest concentrations of each compound tested plus DMSO control, scale bars $=500$ $\mu \mathrm{m}$. Bottom, Quantification of the extent of tube formation was measured as tubule length of HRECs treated with each compound compared to DMSO control. SH-11037 is a positive control. Mean \pm SEM, $\mathrm{n}=6$ wells. Representative results from duplicate experiments. $* \mathrm{P}<0.05$, *** $\mathrm{P}<0.001$ compared to DMSO control (One-way ANOVA with Dunnett's posthoc tests). 


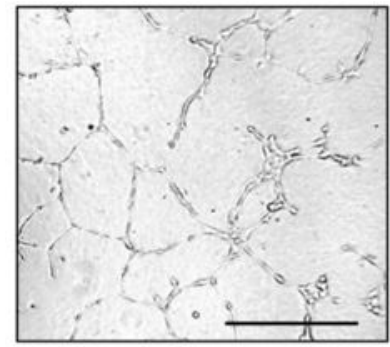

DMSO

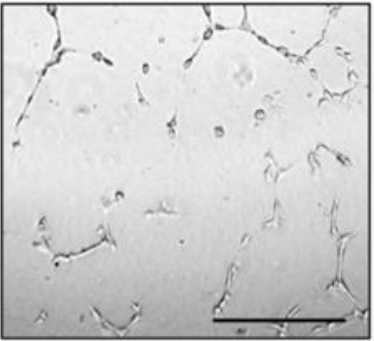

$460.1 \mathrm{nM}$

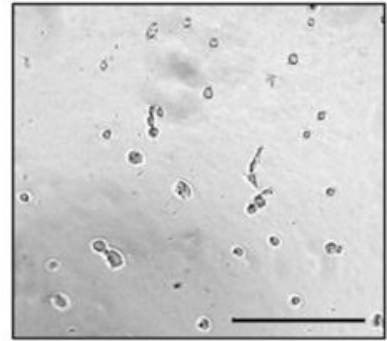

$4610 \mathrm{nM}$

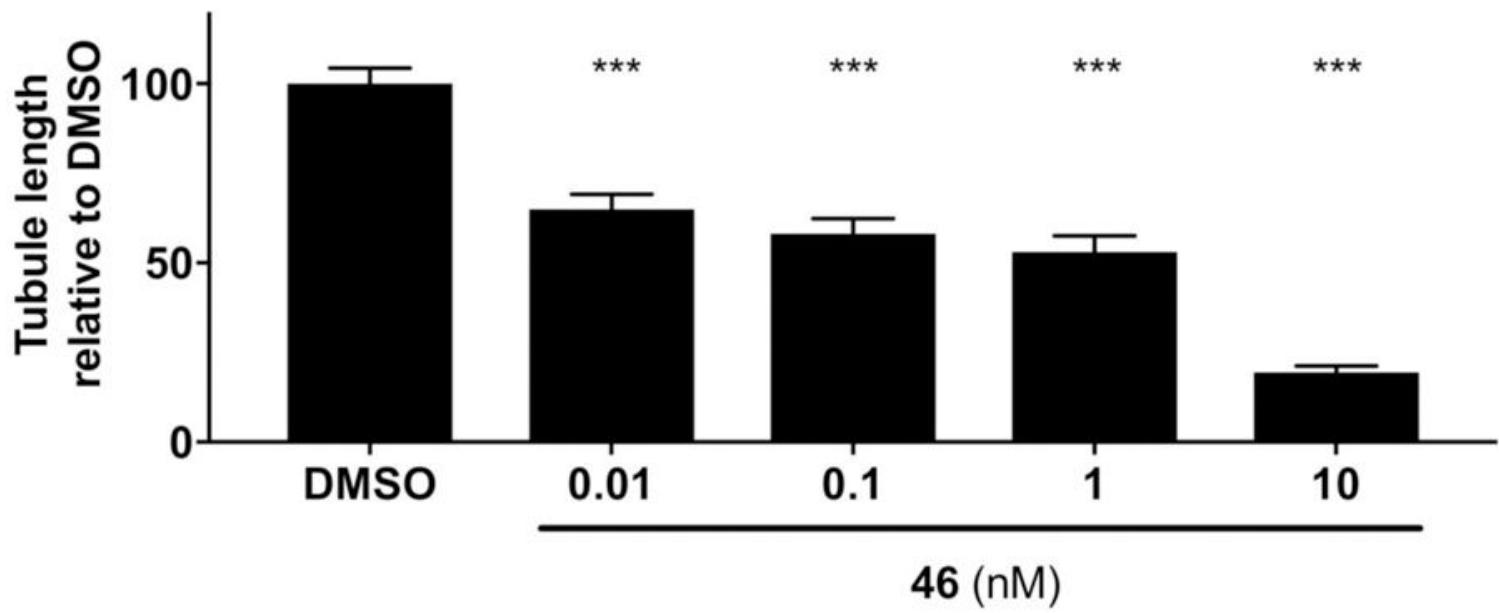

Figure 5.

Highly potent synthetic homoisoflavonoid 46 significantly blocks the ability of HRECs to form tube-like structures. Top, Representative images of the tube formation of HRECs on Matrigel, scale bars $=500 \mu \mathrm{m}$. Bottom, Quantification of the extent of tube formation was measured as tubule length of HRECs treated with compound compared to DMSO control. Mean \pm SEM, $\mathrm{n}=6$ wells. Representative results from duplicate experiments. $* * * \mathrm{P}<0.001$ compared to DMSO control (One-way ANOVA with Dunnett's post-hoc tests). 


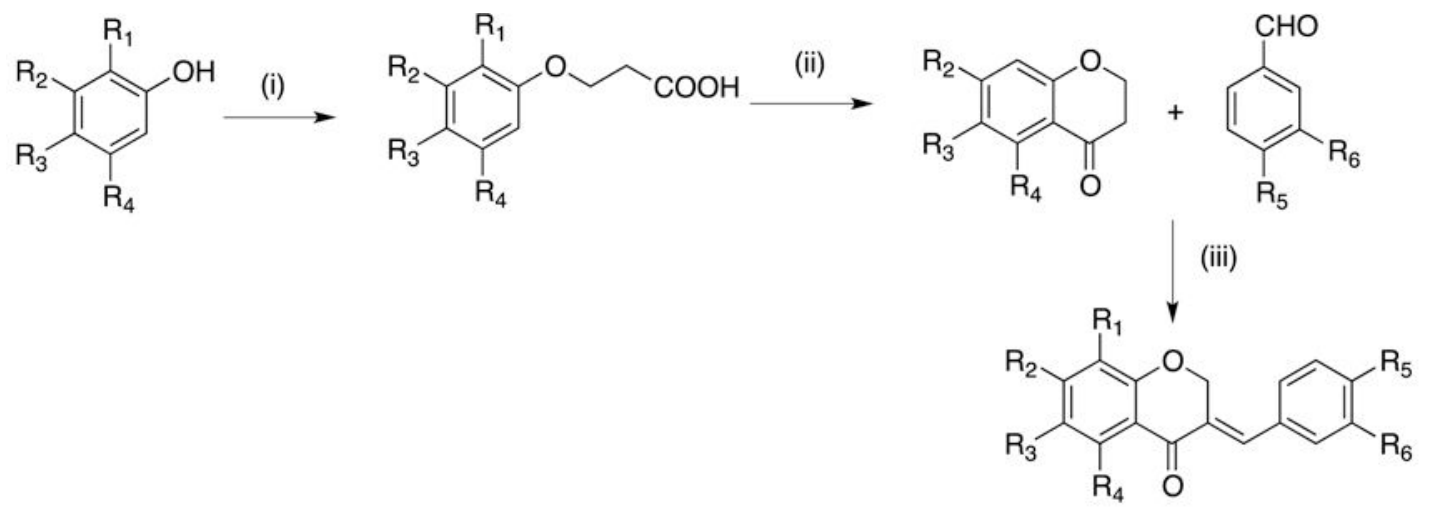

Reagents: (i) $\mathrm{NaH}$; dry Dimethylformamide; 3-Bromopropionic acid (ii) Polyphosphoric acid; $80^{\circ} \mathrm{C}$ (iii) Piperidine; $80^{\circ} \mathrm{C}$

42 $R_{1}=R_{3}=R_{6}=H ; R_{2}=O C H_{3} ; R_{4}=O_{C C H} ; R_{5}=S_{3} H_{3}$
43 $R_{1}=R_{2}=O C H_{3} ; R_{3}=R_{4}=R_{6}=H ; R_{5}=S C H_{3}$
44 $R_{1}=H ; R_{2}=R_{3}=R_{4}=R_{5}=O C H_{3} ; R_{6}=O H$

Scheme 1.

General scheme for synthesis of 3-benzylidene homoisoflavonoids. 
<smiles>COc1ccc(CC2COc3cc(OC)c(OC)c(OC)c3C2)cc1OC</smiles>

(i) Pd/C; Ethanol; $\mathrm{H}_{2}$ atmospheric pressure; room temperature

(ii) Wilkinson's catalyst; Toluene; $\mathrm{H}_{2}$ atmospheric pressure; room temperature

(iii) Iridium catalyst; dry Toluene; $\mathrm{H}_{2} 3$ bar; room temperature

(iv) Trimethylsilyl chloride (8 eq.); Nal (8 eq.); dry Dichloromethane; $0{ }^{\circ} \mathrm{C}$

Scheme 2.

Reactions of Compound 44. (Iridium catalyst $=(S)-(-)-2-[2-($ diphenylphosphino)phenyl]-4isopropyl-2-oxazolium-(1,5)-cyclooctadiene iridium (I) tetrakis(3,5bis(trifluoromethyl)phenyl borate). 


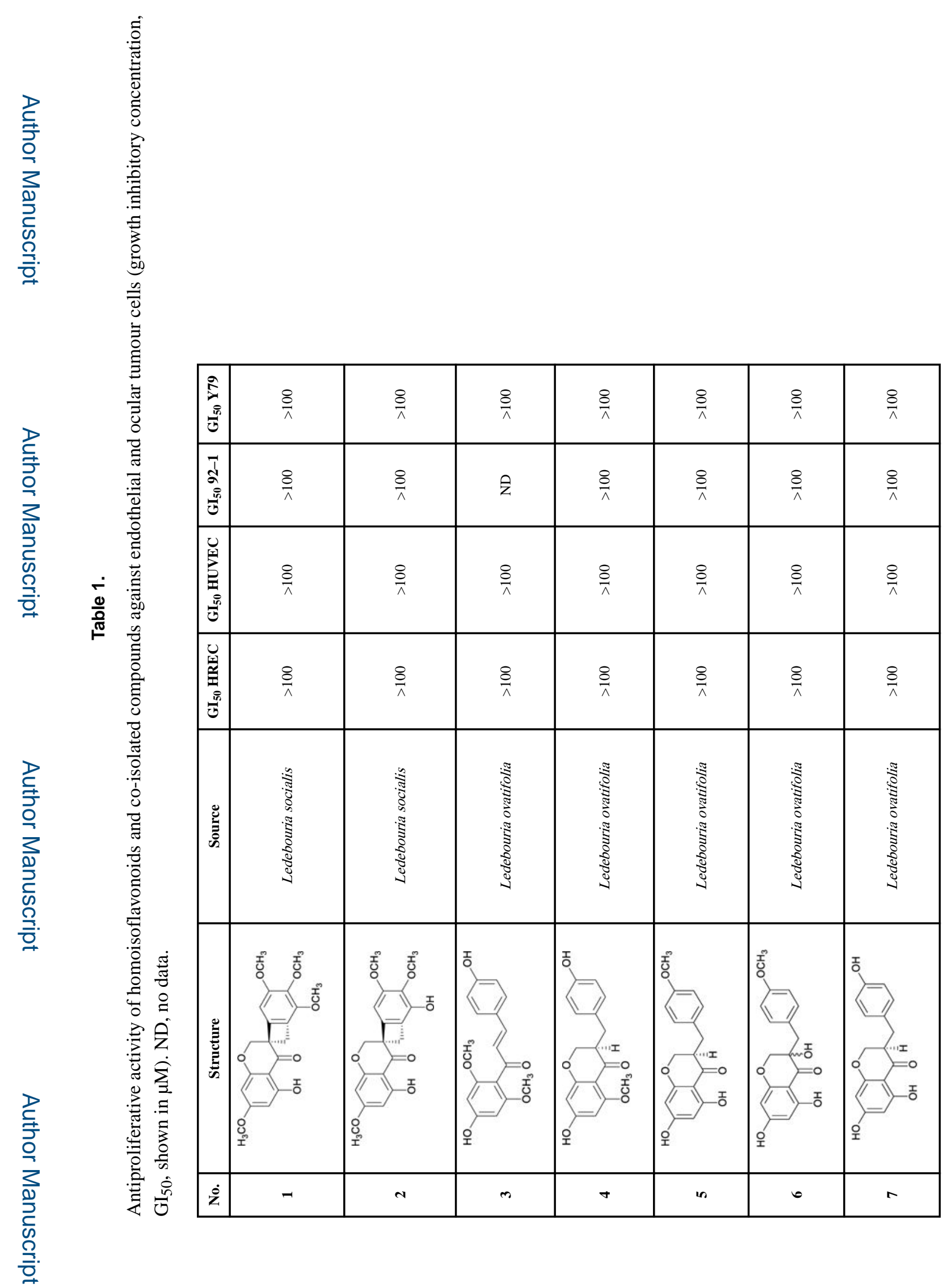

J Nat Prod. Author manuscript; available in PMC 2020 May 24. 


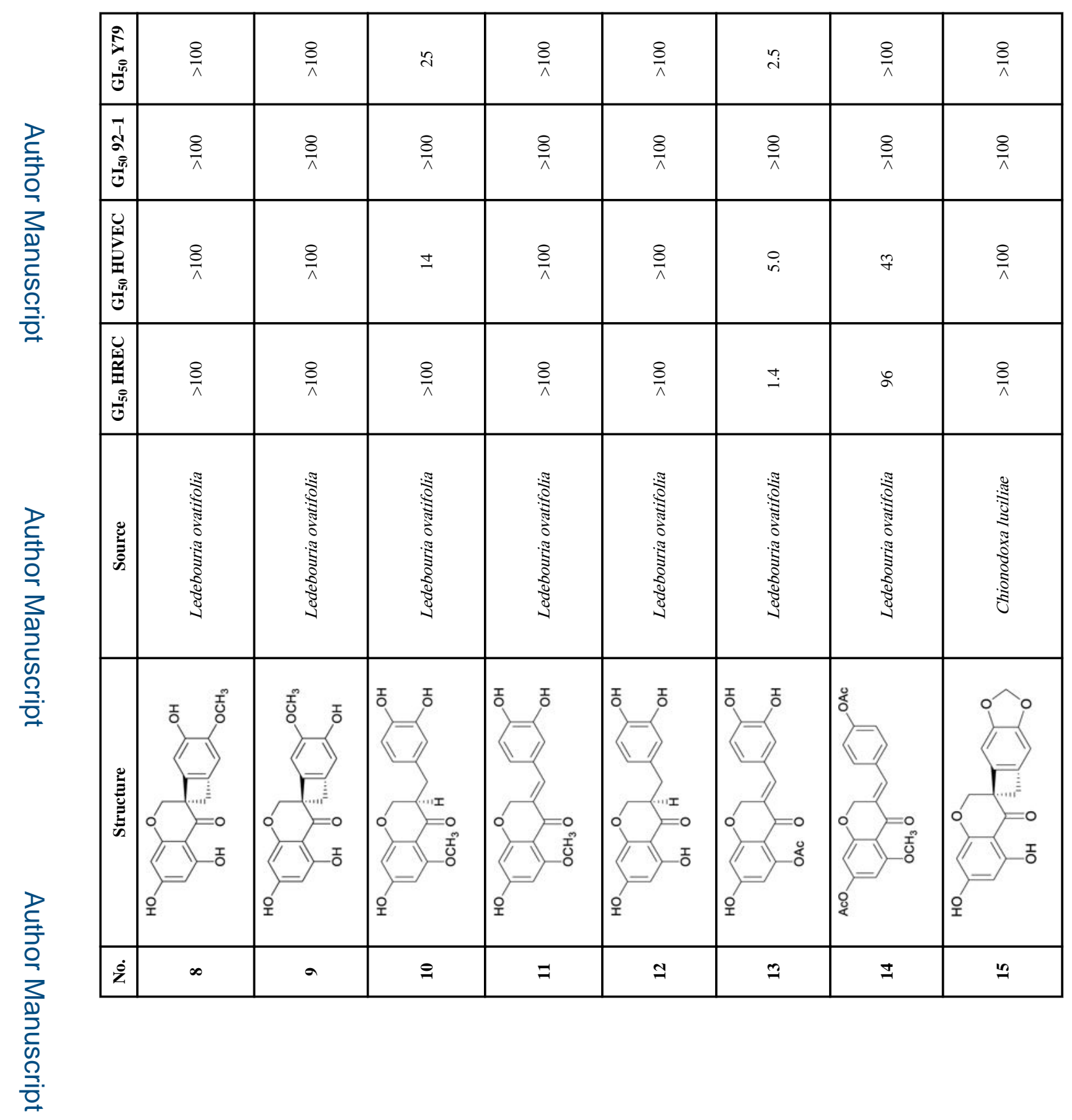

로을 


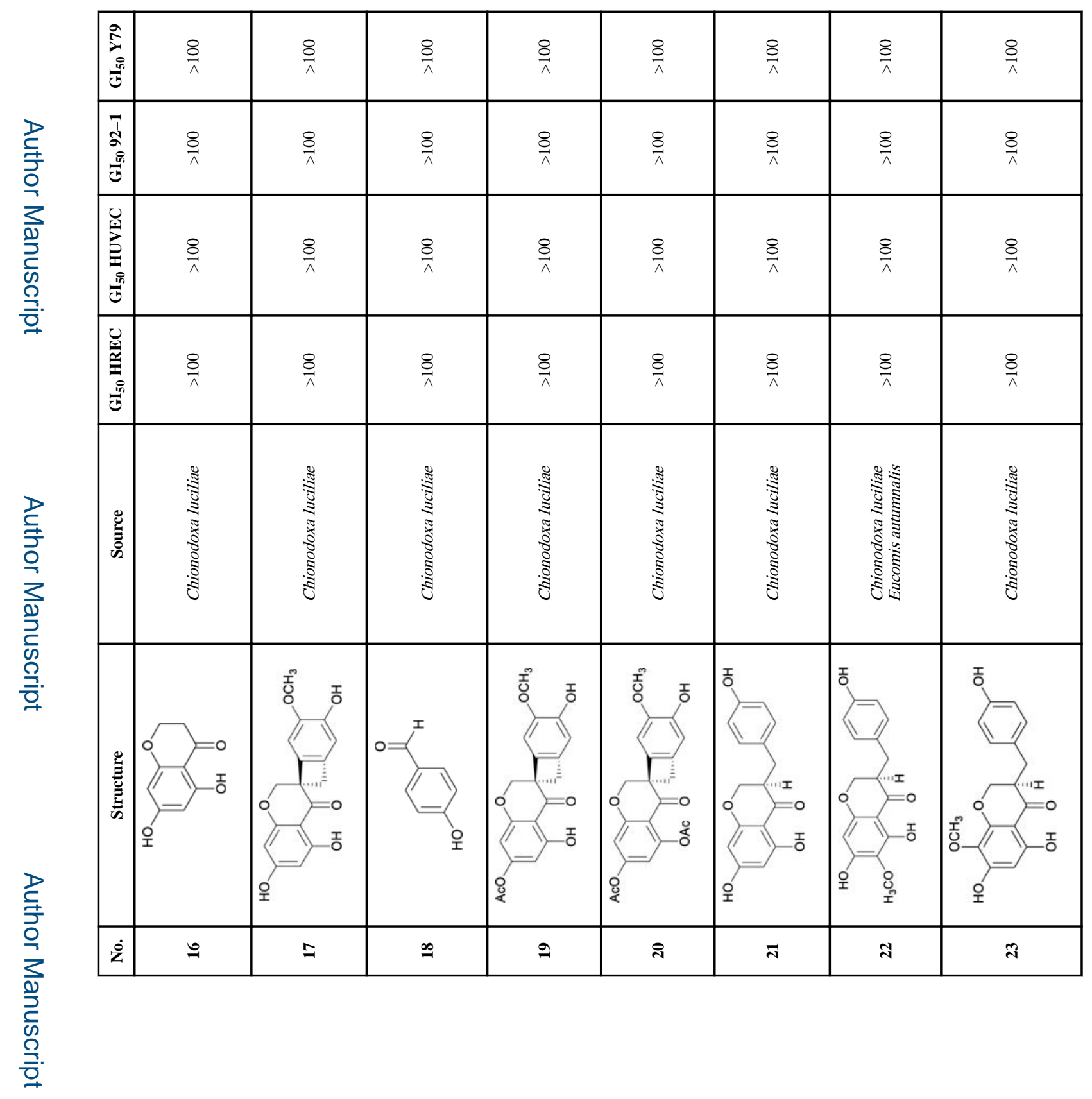

로을 


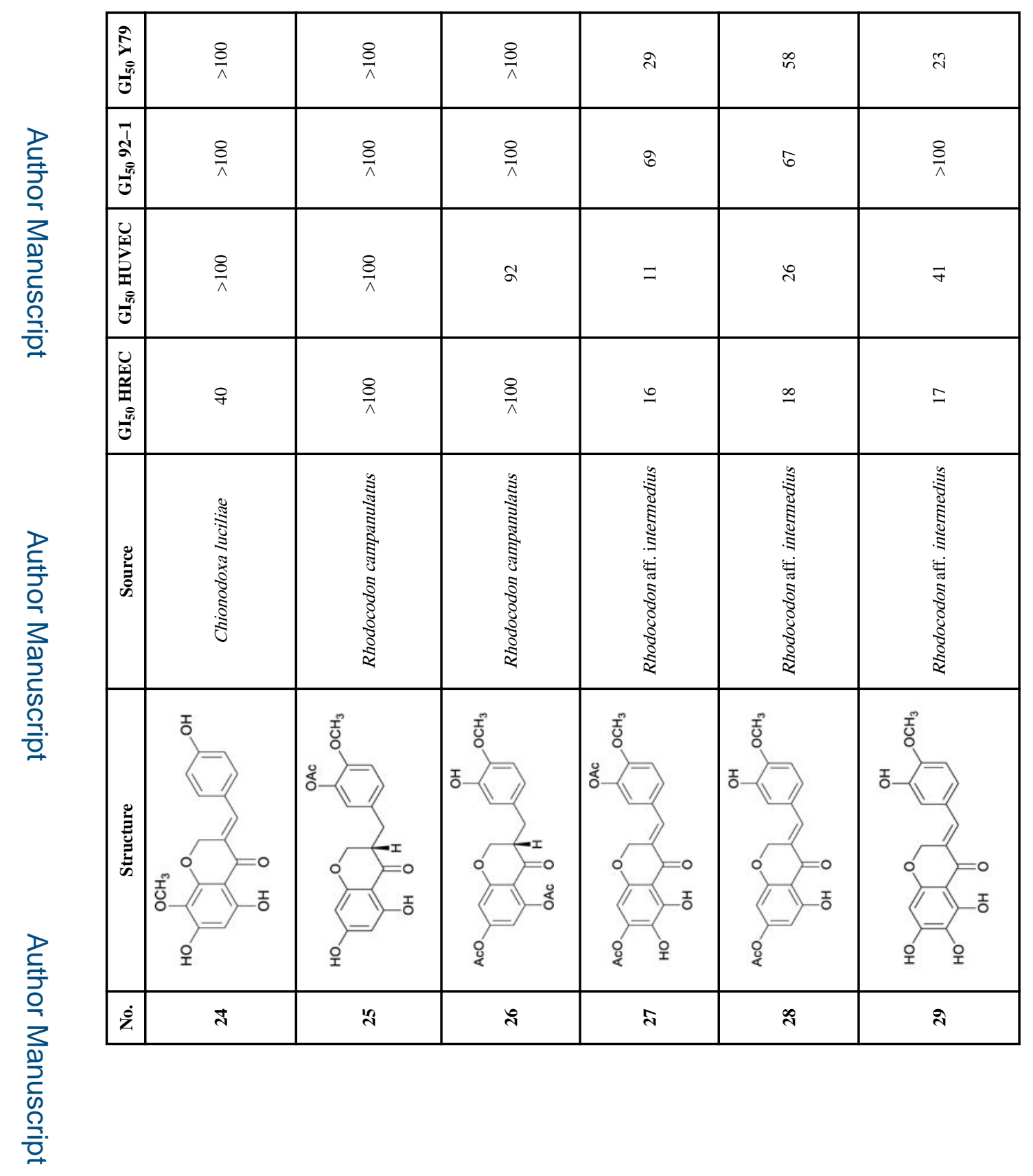

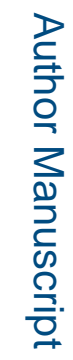




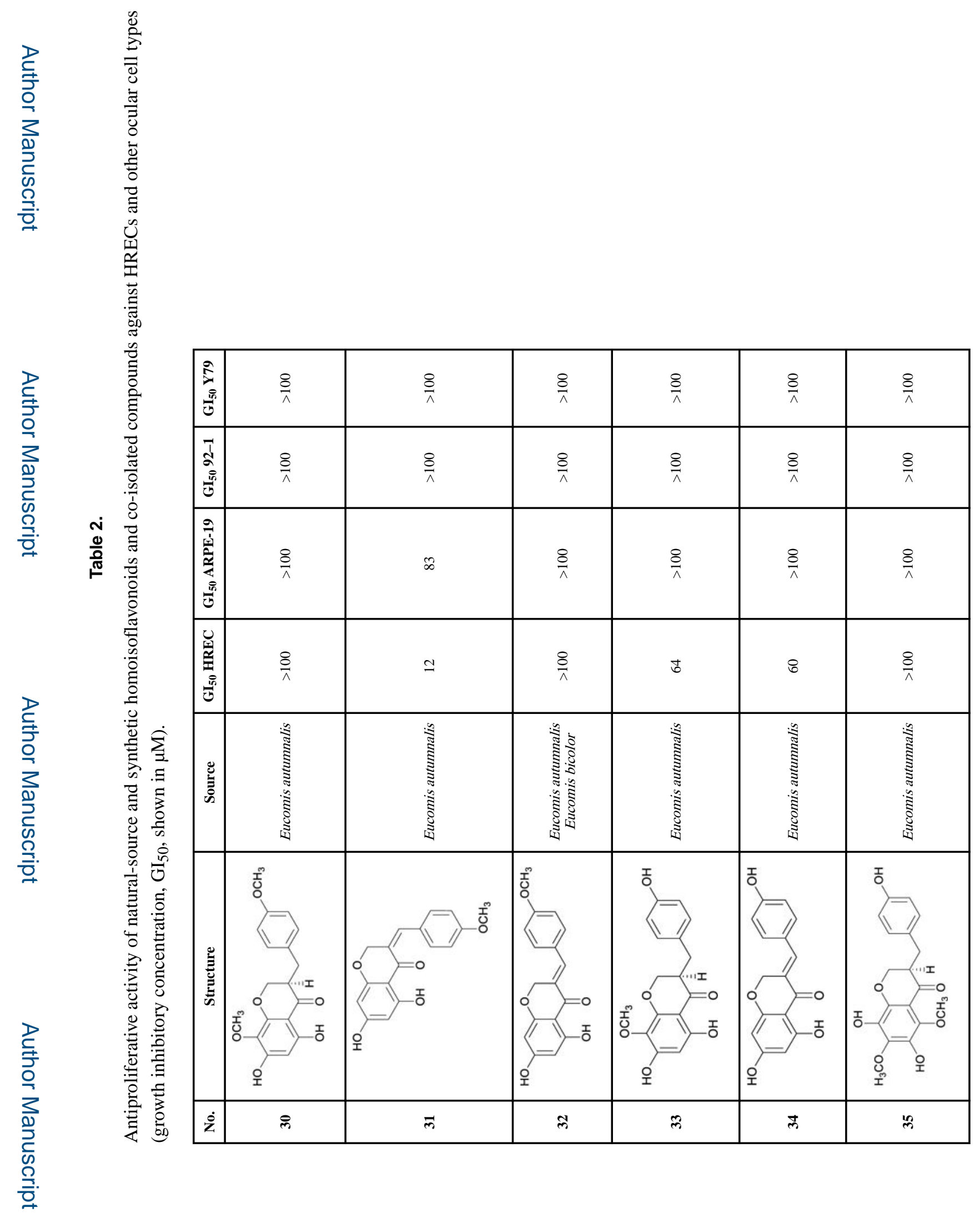

J Nat Prod. Author manuscript; available in PMC 2020 May 24. 


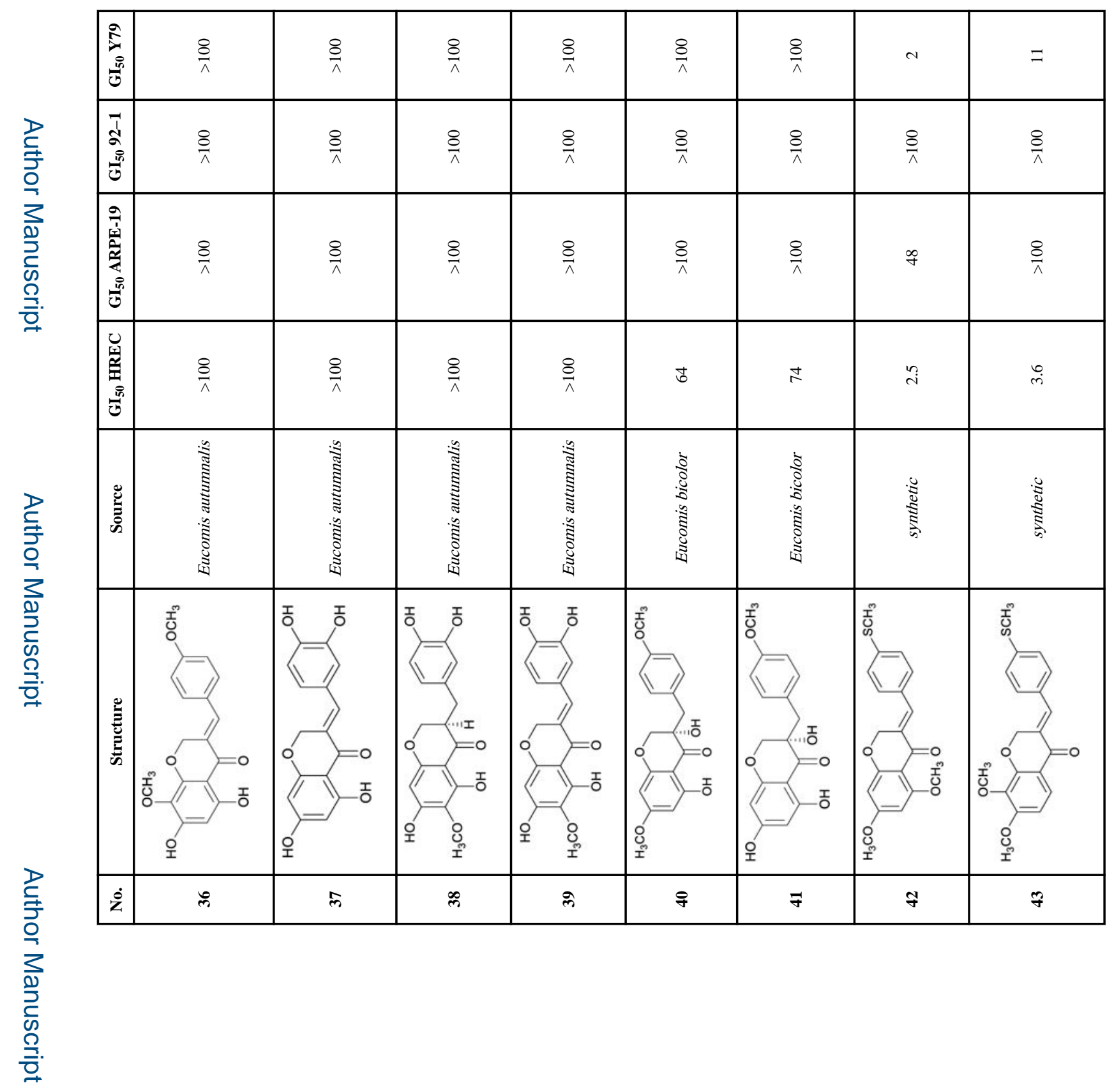

로을 


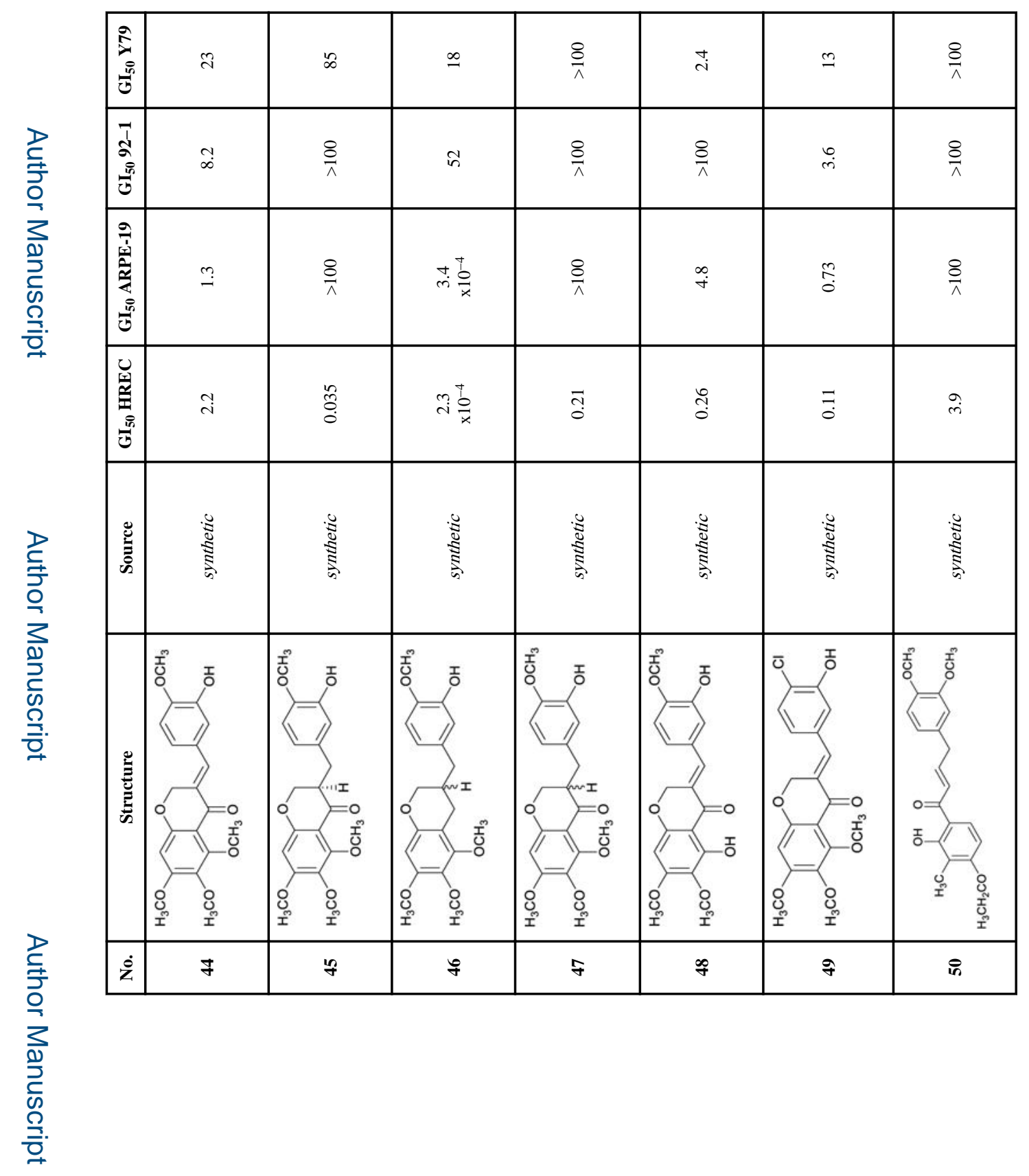

로을 
잉

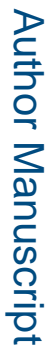

$\stackrel{\hat{v}}{\Xi}$

ठิ

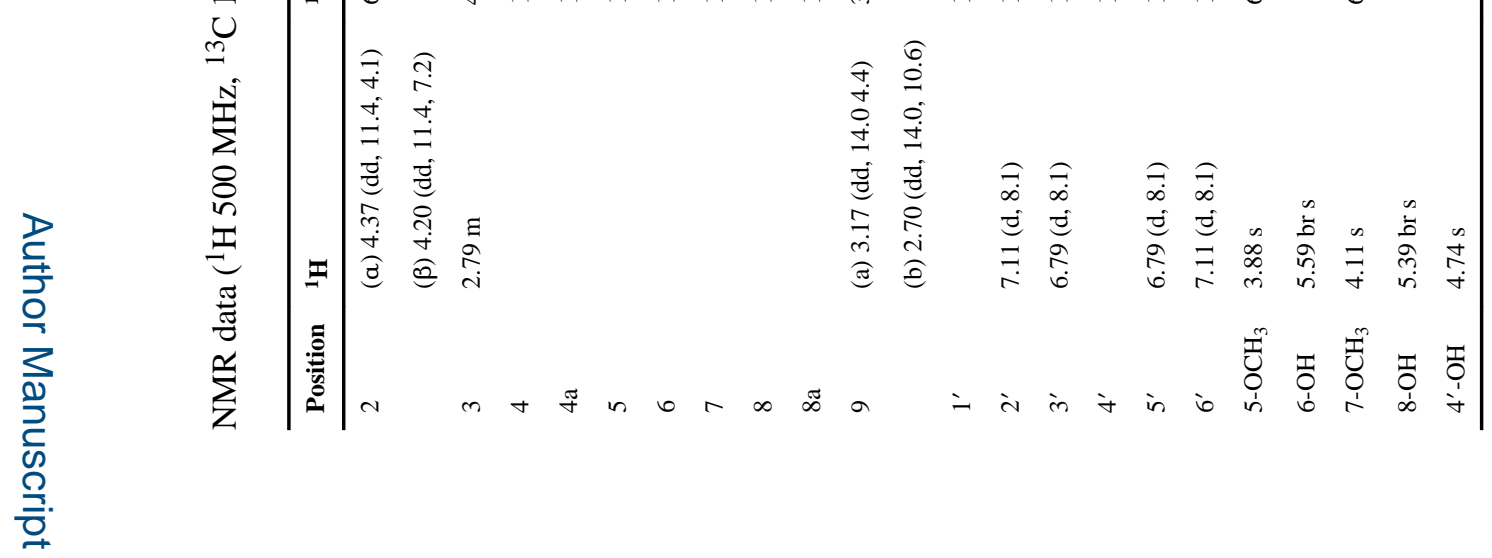

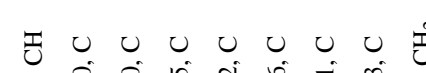

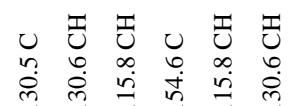

ma

J Nat Prod. Author manuscript; available in PMC 2020 May 24. 


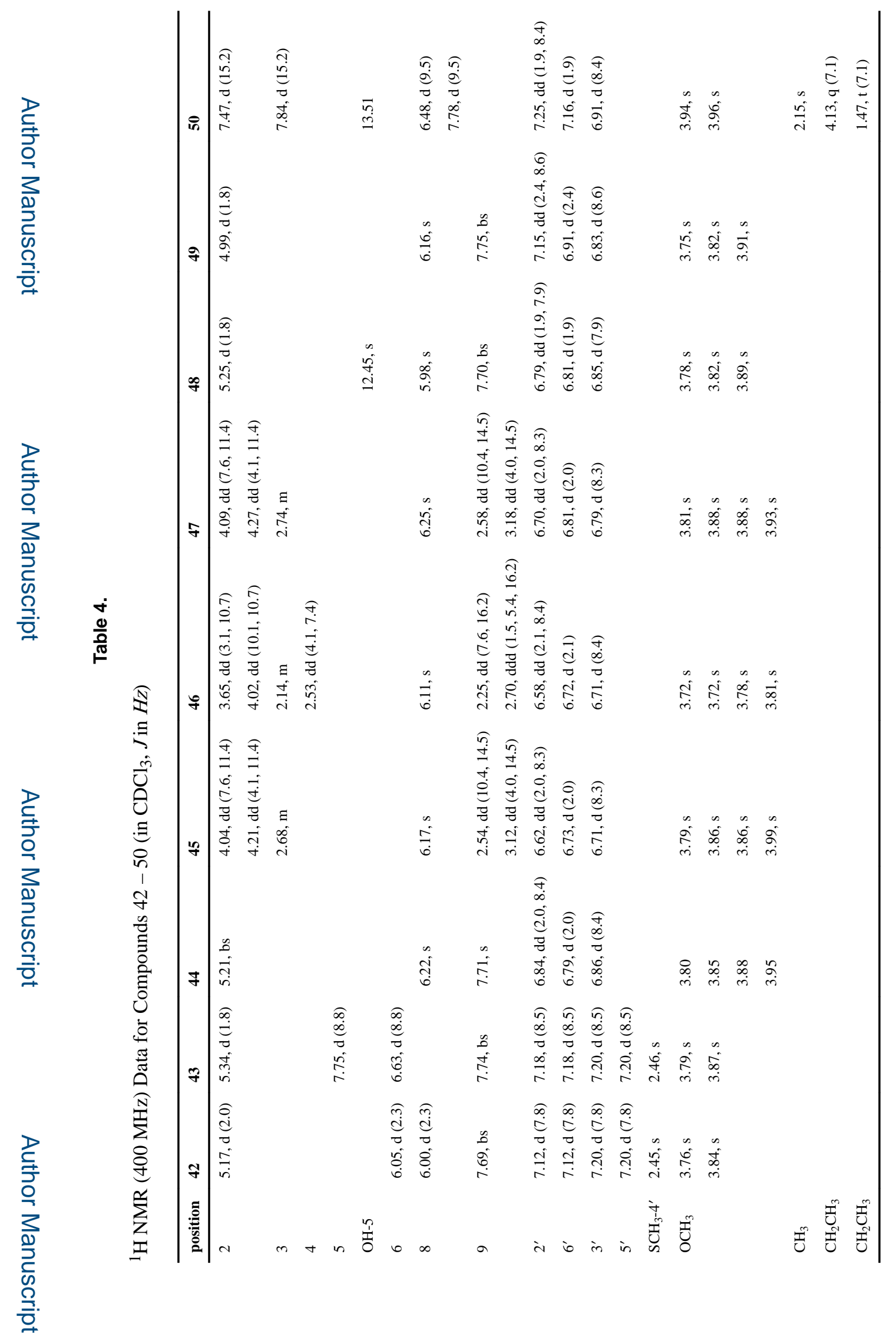

J Nat Prod. Author manuscript; available in PMC 2020 May 24. 


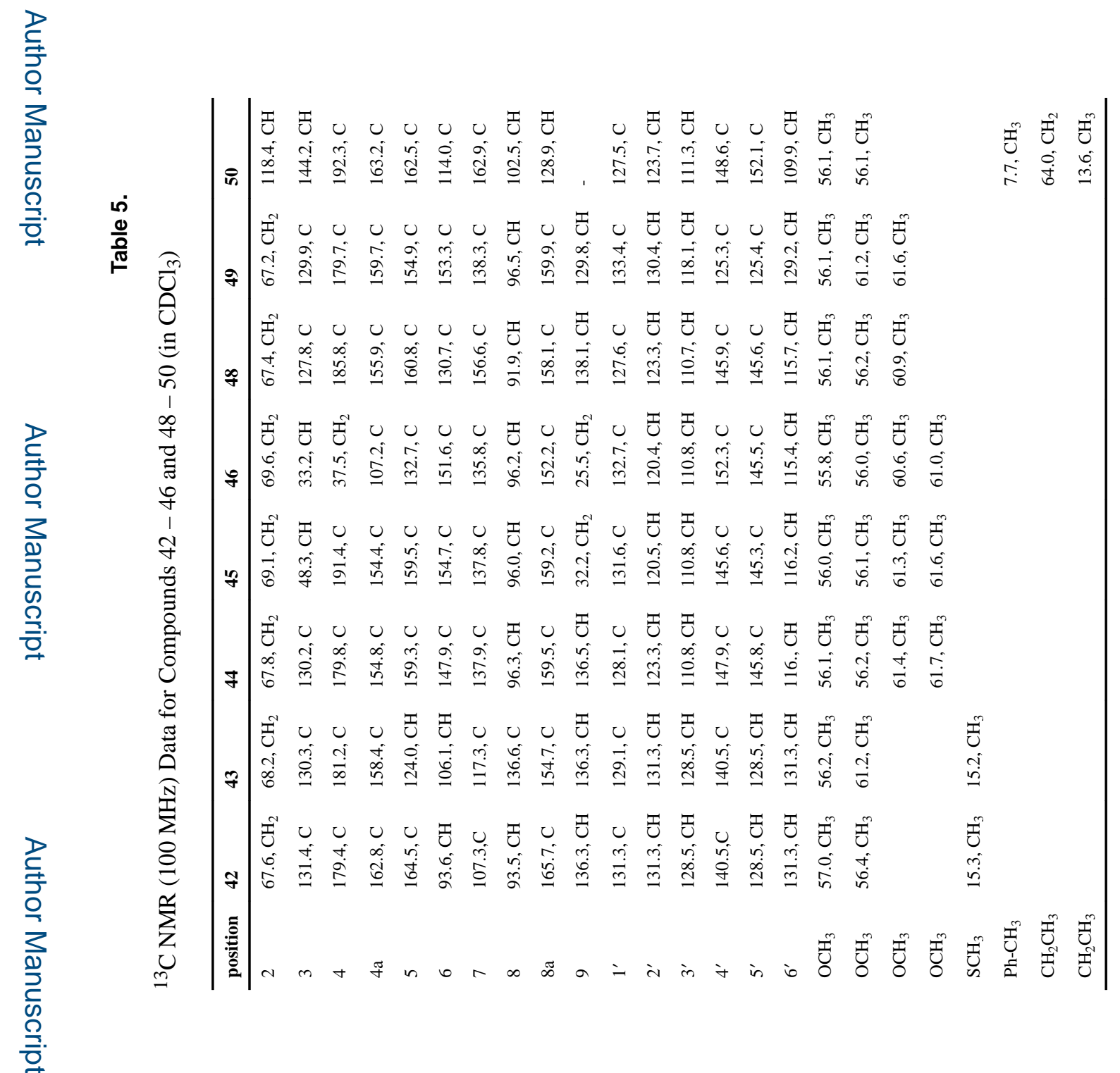

